\title{
Determining the fate of selenium in wheat biofortification: an isotopically labelled field trial study
}

\author{
A. W. Mathers • S. D. Young • S. P. McGrath • \\ F. J. Zhao • N. M. J. Crout • E. H. Bailey
}

Received: 4 May 2017 / Accepted: 8 August 2017 / Published online: 15 August 2017

(C) The Author(s) 2017. This article is an open access publication

\begin{abstract}
Aims The principal aim of this research was to quantify retention of a single, realistic Se biofortification application $\left(10 \mathrm{~g} \mathrm{ha}^{-1}\right)$ in contrasting soils over two growing seasons utilizing an enriched stable Se isotope $\left({ }^{77} \mathrm{Se}\right)$ to discriminate between applied Se and native soil Se.

Methods Isotopically enriched ${ }^{77} \mathrm{Se}\left(\mathrm{Na}_{2} \mathrm{SeO}_{4}\right)$ was applied $\left(10 \mathrm{~g} \mathrm{ha}^{-1}\right)$ to four replicate plots $(2 \mathrm{~m} \times 2 \mathrm{~m})$ of winter wheat, on three contrasting soils on the University of Nottingham farm (UK), at early stem extension in May 2012. Labelled ${ }^{77} \mathrm{Se}$ was assayed in soil and crop fractions by ICP-MS.

Results Topsoil retained a proportion of applied Se at harvest (c. $15-31 \%$ ) with only minor retention in subsoil (2-4\%), although losses were $37-43 \%$. Further analysis of topsoil ${ }^{77} \mathrm{Se}$, the following spring, and at second harvest, suggested that labelled Se retained in soil was fixed and uptake by a following crop was negligible.

Conclusions Prolonged biofortification leads to accumulation of Se in soil but the retained Se has very low bioavailability and mobility. The time required to double
\end{abstract}

Responsible Editor: Ismail Cakmak.

\footnotetext{
A. W. Mathers · S. D. Young $(\bowtie) \cdot$ N. M. J. Crout

E. H. Bailey

Division of Agricultural and Environmental Sciences, School of Biosciences, University of Nottingham, Sutton Bonington Campus, Leicestershire, Loughborough LE12 5RD, UK

e-mail: scott.young@nottingham.ac.uk

S. P. McGrath · F. J. Zhao

Rothamsted Research, Hertfordshire, Harpenden AL5 2JQ, UK
}

the soil Se content would be about 500 years. However, reincorporation of cereal straw could provide a residual source of Se for a following crop, depending on timing and management.

Keywords Selenium - Biofortification - Wheat . Enriched stable isotope $\cdot$ Se fixation in soil $\cdot$ Straw

\section{Introduction}

Agronomic biofortification with Se-enriched fertilisers is an effective means of increasing dietary Se intake by humans and animals (Fordyce 2005; Broadley et al. 2010). In biofortification studies selenium is typically applied either as sodium selenite $\left(\mathrm{Na}_{2} \mathrm{SeO}_{3}\right)$ or sodium selenate $\left(\mathrm{Na}_{2} \mathrm{SeO}_{4}\right)$, although application of other forms (e.g. $\mathrm{K}_{2} \mathrm{SeO}_{4}, \mathrm{BaSeO}_{4}$ ), including commercial compound Se fertilisers (e.g. Selcote Ultra ${ }^{\circledR}$, Top Stock ${ }^{\circledR}$ ) has also been studied (Gissel-Nielsen 1998; Gupta and Gupta 2002; Valle et al. 2002; Broadley et al. 2010). Application of Se may be carried out either by incorporating Se-enriched granular fertilizers or by spraying a liquid drench directly onto the crop canopy or soil (Broadley et al. 2010). Chilimba et al. (2012a) observed that Se uptake by maize was similar for liquid and solid applications of selenate to soil. Despite the wide range of application rates employed in cereal crop Se biofortification studies, from $<10$ to $500 \mathrm{~g} \mathrm{ha}^{-1}$ (Yläranta 1983), uptake of Se by arable crops is widely reported as being a linear function of application rate (Ducsay and Ložek 2006; Stroud et al. 2010b; Broadley 
et al. 2010, Chilimba et al. 2012a; Galinha et al. 2012; Wang et al. 2013); this is also true of herbage sward studies (Whelan 1989; Rimmer et al. 1990; Shand et al. 1992; Valle et al. 2002). It is also widely accepted that crop uptake of selenate $\left(\mathrm{Se}^{\mathrm{VI}}\right)$ exceeds that of selenite $\left(\mathrm{Se}^{\mathrm{IV}}\right.$ ) (Shand et al. 1992; Chen et al. 2002; Zhao et al. 2005; Galinha et al. 2012, Ros et al. 2016) mainly because selenate is more soluble in soil within the $\mathrm{pH}$ range of arable soils (Fleming 1980; Jacobs 1989; Neal 1995) making it more bioavailable (Zayed et al. 1998; Li et al. 2008; Stroud et al. 2010b). Yläranta (1983) observed that application of just 10-20 $\mathrm{g} \mathrm{ha}^{-1} \mathrm{Na}_{2} \mathrm{SeO}_{4}$ $\left(\mathrm{Se}^{\mathrm{VI}}\right)$ was sufficient to produce barley grain Se concentrations of $100-200 \mu \mathrm{g} \mathrm{kg}^{-1}$, whereas over $100 \mathrm{~g} \mathrm{ha}^{-1}$ $\mathrm{Na}_{2} \mathrm{SeO}_{3}\left(\mathrm{Se}^{\mathrm{IV}}\right)$ was needed to achieve similar concentrations. Gupta et al. (1993) observed that application of $10 \mathrm{~g} \mathrm{ha}^{-1} \mathrm{Na}_{2} \mathrm{SeO}_{4}$ increased barley grain Se concentrations by approximately $200 \mu \mathrm{g} \mathrm{kg}^{-1}$ above controls, whereas the same application rate of $\mathrm{Na}_{2} \mathrm{SeO}_{3}$ apparently had no measureable effect on grain Se concentration.

Whilst the uptake of Se by crops in biofortification studies has been studied extensively, the retention of residual $\mathrm{Se}$ in the soil has received limited attention (Keskinen et al. 2011). This issue needs to be addressed if Se biofortification is to be implemented on a large scale and over long time periods. Extended application of Se to soils has implications for water quality and for long-term micronutrient management and supply of this scarce resource. Currently, the fate of Se from enriched fertilisers, and the underlying mechanisms which dictate this, are not fully understood (Alfthan et al. 2011). Quantification of applied Se retained in soil is very difficult; this is due to the very small amounts of Se typically applied (c. 10-20 $\mathrm{g} \mathrm{ha}^{-1}$ ). For example, complete retention of Se at a biofortification rate of $10 \mathrm{~g} \mathrm{Se}$ $\mathrm{ha}^{-1}$ would result in an increase in concentration of just $4 \mu \mathrm{g} \mathrm{Se} \mathrm{kg}{ }^{-1}$, assuming a topsoil mass of $2500 \mathrm{t} \mathrm{ha}^{-1}$ (topsoil depth $=20 \mathrm{~cm}$; bulk density $=1.25 \mathrm{~g} \mathrm{~cm}^{-3}$ ). This is negligible $(0.56 \%)$ in comparison with the UK average soil Se concentration of $710 \mu \mathrm{g} \mathrm{kg}^{-1}$ (Rawlins et al. 2012) and would be virtually impossible to measure within the span of a short term research project. However, this problem can be overcome by using an enriched stable isotope of $\mathrm{Se}$, such as ${ }^{77} \mathrm{Se}$ (natural abundance $7.63 \%)$. If ${ }^{77} \mathrm{Se}(100 \%$ abundance) were applied at a rate of $10 \mathrm{~g} \mathrm{ha}^{-1}\left(4 \mathrm{\mu g}^{77} \mathrm{Se} \mathrm{kg}^{-1}\right)$ this would equate to a $7.5 \%$ increase in soil ${ }^{77} \mathrm{Se}$, bringing quantification of retention within analytical reach. Chilimba et al. (2012a) used enriched ${ }^{74} \mathrm{Se}$ (natural abundance
$0.89 \%$ ) to determine residual fertilizer effects in maize grown on acidic soils in Malawi. In principle, the very low natural abundance of ${ }^{74} \mathrm{Se}$ would make it an ideal tracer for studying the fate of Se. However mass interferences to inductively coupled plasma mass spectrometry (ICP-MS) analysis from ${ }^{74} \mathrm{Ge}$ and incomplete removal of iron polyatomics (possibly ${ }^{57} \mathrm{Fe}-\mathrm{OH}$ and ${ }^{56} \mathrm{Fe}-$ $\mathrm{OH}_{2}$ ) made quantification of ${ }^{74} \mathrm{Se}$ in soil samples problematic. In a recent field incubation study of selenium fractionation and speciation changes in three soil types, Di Tullo et al. (2016) used enriched ${ }^{77} \mathrm{Se}$ to distinguish between added Se and native soil Se.

The primary aim of this paper was to quantify retention of a single, realistic Se biofortification application $\left(10 \mathrm{~g} \mathrm{ha}^{-1}\right)$ in contrasting soils over two growing seasons utilizing an enriched stable Se isotope $\left({ }^{77} \mathrm{Se}\right)$ to discriminate between applied $\mathrm{Se}$ and native soil Se. Secondary aims were to determine (i) the bioavailability of residual soil Se, (ii) the period in the growing season during which losses of added selenate from soil occurred, (iii) the rate of selenate immobilization in soil, and (iv) the likely contribution to available Se from biofortified wheat straw ploughed into soil. The stable enriched isotope ${ }^{77} \mathrm{Se}$ was chosen to enable a full mass balance on the fate of Se applied to a wheat crop, as (i) it is the second least abundant isotope of Se (after ${ }^{74} \mathrm{Se}$ ) and (ii) at mass 77 it was thought that there would be a reduced chance of spectral interferences to ICP-MS analysis encountered at a mass:charge ratio $(\mathrm{m} / \mathrm{z})$ of 74 .

\section{Materials and methods}

Site selection

Three fields on the University of Nottingham farms, with contrasting soil series, were selected for the biofortification experiment. These were, nominally (i) Dunnington Heath series (clay loam) Sutton Bonington Farm (grid ref.: $52^{\circ} 50^{\prime} 08.19^{\prime \prime} \mathrm{N}-1^{\circ} 14^{\prime} 51.21^{\prime \prime} \mathrm{W}$ ), (ii) Newport series (sandy clay loam) Bunny farm (grid ref.: $52^{\circ} 51^{\prime} 28.63^{\prime \prime} \mathrm{N}-1^{\circ} 07^{\prime} 25.36^{\prime \prime} \mathrm{W}$ ) and (iii) Worcester series (clay loam) Bunny Farm (grid ref.: 52 $51^{\prime} 14.85^{\prime \prime}$ $\left.\mathrm{N}-1^{\circ} 07^{\prime} 35.53^{\prime \prime} \mathrm{W}\right)$. Each site was sown with winter wheat (Triticum aestivum) in September 2011 following a pre-existing farm management strategy. The varieties planted were JB Diego at the Dunnington Heath (DH) and Worcester (WOR) sites and Santiago at the Newport site (NEW). At each site four replicate treatment plots 
$(2 \mathrm{~m} \times 2 \mathrm{~m})$ were established within a $2 \times 8 \mathrm{~m}$ block between the field boundary/headland and the first cultivation tramline. Plot corners were recorded using lineof-site markers in the headland to enable relocation of the plots. Plough direction was recorded as ploughing causes a shift in the position of the topsoil, estimated by Lane and McGrath (1994) as $0.24 \mathrm{~m}$ parallel to, and $0.13 \mathrm{~m}$ perpendicular to, the original position of the topsoil in the direction of cultivation.

\section{Preparation of selenate-77 stock solutions}

Selenite-77 $\left({ }^{77} \mathrm{Se}^{\mathrm{IV}}\right)$ and selenate-77 $\left({ }^{77} \mathrm{Se}^{\mathrm{VI}}\right)$ were prepared from an elemental stock of enriched ${ }^{77} \mathrm{Se}^{0}$ (50 mg; $99.2 \%$ atom \%), purchased from Isoflex, USA, following the method described by Collins et al. (2006). Selenite-77 $\left(\mathrm{Se}^{\mathrm{IV}}\right)$ was prepared by dissolving $25 \mathrm{mg}$ ${ }^{77} \mathrm{Se}^{0}$ in $10 \mathrm{~mL} 70 \% \mathrm{HNO}_{3}$ in a $100 \mathrm{~mL}$ conical flask and heating at $60{ }^{\circ} \mathrm{C}$ on a teflon-coated graphite block digester until dry. The resulting desiccated material was dissolved in $100 \mathrm{~mL} 2 \% \mathrm{HNO}_{3}$ and stored in the dark at room temperature. Selenate- $77\left(\mathrm{Se}^{\mathrm{VI}}\right)$ was prepared by dissolving $25 \mathrm{mg}{ }^{77} \mathrm{Se}^{0}$ in $5 \mathrm{~mL} 30 \% \mathrm{H}_{2} \mathrm{O}_{2}$ and $5 \mathrm{~mL}$ $2.0 \mathrm{M} \mathrm{KOH}$ in a $100 \mathrm{~mL}$ conical flask and heating at $90{ }^{\circ} \mathrm{C}$ on a teflon-coated graphite block digester until dry. The resulting desiccated material was dissolved in $10 \mathrm{~mL} 30 \% \mathrm{H}_{2} \mathrm{O}_{2}$ and heated at $90{ }^{\circ} \mathrm{C}$ until dry twice more. Finally the remaining material was then dissolved in $100 \mathrm{~mL}$ of $2 \% \mathrm{HNO}_{3}$ and stored in the dark at room temperature. Stock solution concentrations were calculated, from the original isotopic mass used, as 231 and $259 \mathrm{mg} \mathrm{L}^{-1}$ of ${ }^{77} \mathrm{Se}^{\mathrm{IV}}$ and ${ }^{77} \mathrm{Se}^{\mathrm{VI}}$ respectively. The purity of ${ }^{77} \mathrm{Se}$ in each stock solution was confirmed by $\mathrm{Se}$ analysis by ICP-MS and the speciation of each ${ }^{77} \mathrm{Se}$ stock solution was confirmed by coupled anion exchange liquid chromatography (LC-ICP-MS) analysis.

\section{Selenium application to experimental plots}

Selenium was applied to each plot as aqueous ${ }^{77} \mathrm{Se}^{\mathrm{VI}}$ in mid-May 2012 at a rate of $10 \mathrm{~g} \mathrm{ha}^{-1}\left(1.0 \mathrm{~L} \mathrm{~m}^{-2}\right)$ using a knapsack sprayer (16 L Vermorel 2000 pro, Berthoud Jadin). Weather conditions experienced at the time of application at the DH site were dry, warm and still (14th May 2012), whereas conditions experienced at the NEW and WOR sites were intermittent rainfall, cool temperatures and moderate winds (17th May 2012). The timing of application (at all sites) coincided with early stem extension (growth stage 31/32, Zadoks et al.
1974; Feekes scale 6-7, Large 1954). Once applied, the crop was irrigated with $16 \mathrm{~L}$ de-ionized water at each site $\left(1 \mathrm{~mm}\right.$ depth) intended to limit retention of ${ }^{77} \mathrm{Se}$ on the foliage.

Sample collection and processing

Soil samples were collected using a stainless steel auger from within the central square metre of each plot $(2 \mathrm{~m} \times 2 \mathrm{~m})$. Topsoil was taken from a depth interval of 0-20 cm, and subsoils from a depth of $20-40 \mathrm{~cm}$. Samples were collected from the four corners and centre of the central $1 \mathrm{~m}^{2}$ of each of the selenium application plots and combined. This was repeated for the four replicate plots and again repeated for the three study sites. The soil from each subplot was sieved to $<2 \mathrm{~mm}$, homogenised by the cone sampling method, finely ground, sub-sampled for analysis and the four subplots analysed separately. Prior to ${ }^{77} \mathrm{Se}$ application, soils from each plot were sampled to act as individual plot controls. Following ${ }^{77} \mathrm{Se}$ application, soils were sampled at (i) harvest 2012 (H1, mid-August), (ii) spring 2013 (S2, mid-May) and (iii) (residual) harvest 2013 (H2, mid-August), to quantify retention of ${ }^{77} \mathrm{Se}$ in soil (i) at the end of a single growing season, (ii) after a winter of leaching and (iii) at the end of a second growing season, respectively. No subsoil samples were taken at $\mathrm{H} 2$.

Crops were sampled at $\mathrm{H} 1$ and $\mathrm{H} 2$ by removing the entire central square metre of each plot by hand at $10 \mathrm{~cm}$ above ground level with stainless steel scissors. Wheat ears and straw were separated following collection. Ears were dried at $40{ }^{\circ} \mathrm{C}$ in an oven (Scientific Laboratory Supplies Ltd) and then threshed to separate chaff and grain, which were milled separately in an ultracentrifugal mill fitted with $0.5 \mathrm{~mm}$ titanium screen (Model ZM200, Retsch). Straw was sub-sampled (c. $20 \%$ of total), dried at $30{ }^{\circ} \mathrm{C}$ in a temperaturecontrolled room and chopped in a cutting mill (Model SM100, Retsch) fitted with a $1 \mathrm{~mm}$ stainless steel screen. As a check on possible local variation in the background ${ }^{77} \mathrm{Se}:{ }^{78} \mathrm{Se}$ isotopic ratio, crop samples were collected from within the same fields at each site, but outside the area of ${ }^{77} \mathrm{Se}$ application ( $>30 \mathrm{~m}$ away).

Soil characterisation

Soil $\mathrm{pH}$ was determined using a $\mathrm{pH}$ meter (Model pH 209, HANNA Instruments) with combined glass electrode $(\mathrm{Ag} / \mathrm{AgCl})$ on a suspension of $5 \mathrm{~g}( \pm 0.5 \mathrm{~g})$ 
air-dried soil $(<2 \mathrm{~mm})$ in $12.5 \mathrm{~mL}$ of Milli-Q water $(18.2 \mathrm{M} \Omega \mathrm{cm})$ after shaking end-over-end for $30 \mathrm{~min}$ at $27 \mathrm{rpm}$. Soil texture was determined by laser granulometry following initial treatment with $40 \%$ $\mathrm{H}_{2} \mathrm{O}_{2}$ and dispersion in $25 \mathrm{~mL}$ Calgon ${ }^{\mathrm{TM}}$ solution (3.5\% sodium hexametaphosphate and $0.7 \%$ sodium carbonate). Following the study of Konert and Vandenberghe (1997) the clay fraction was taken as $<8 \mu \mathrm{m}$ to permit comparison with traditional methods. Total soil carbon concentration (SC) was determined by combustion at $900{ }^{\circ} \mathrm{C}$ in an Elemental Analyser (Model Flash EA1112, CE Instruments). Soil inorganic carbon (SIC) was determined in a Shimadzu TOC-VCPH instrument coupled with an SSM-5000A solids module (Shimadzu UK Ltd). Soil organic carbon (SOC) was determined by difference between SC and SIC. Soil iron $(\mathrm{Fe})$, aluminium $(\mathrm{Al})$ and manganese oxide $(\mathrm{Mn})$ contents were determined by inductively coupled plasma mass spectrometry (ICP-MS) following dissolution in citrate bicarbonate dithionite (CBD). Olsen phosphate concentration was measured following extraction in $0.5 \mathrm{M} \mathrm{NaHCO}_{3}$. Total soil Se concentrations (control plot soils only) were determined by ICP-MS following $\mathrm{HNO}_{3}-\mathrm{HClO}_{4}$ - $\mathrm{HF}$ digestion of $0.2 \mathrm{~g}$ in $2 \mathrm{~mL} 70 \%$ TAG $\mathrm{HNO}_{3}, 1 \mathrm{~mL} 60 \% \mathrm{HClO}_{4}$ and $2.5 \mathrm{~mL} 70 \%$ hydrofluoric acid (HF) in perfluoroalkoxy (PFA) digestion vessels heated in a 48-place teflon-coated graphite block digester (Model A3, Analysco Ltd).

Release of Se to soil from straw decomposition

The potential contribution from incorporated crop residues to plant-available Se was investigated by measuring short-term $(0-30 \mathrm{~d})$ release of labelled Se $\left({ }^{77} \mathrm{Se}_{\text {fert }}\right)$ from wheat straw from harvest $\mathrm{H} 1$, following incorporation into moist topsoil samples. Several amounts of milled ${ }^{77}$ Se-enriched straw from $\mathrm{H} 1$ of the DH site $(0$, $200,500$ and $1000 \mathrm{mg})$ and $5 \mathrm{~g}( \pm 0.05 \mathrm{~g})$ moist $(80 \%$ AWC), $<4 \mathrm{~mm}$ sieved soil (Wick series, arable topsoil, sampled at the University of Nottingham Farm, Sutton Bonington, grid ref.: $52^{\circ} 49^{\prime} 49.50^{\prime \prime} \mathrm{N}-1^{\circ} 14^{\prime} 18.83^{\prime \prime} \mathrm{W}$ ) were incubated at $21^{\circ} \mathrm{C}$, for different lengths of time (5, 10, 15, 20 and 30 days). The ${ }^{77} \mathrm{Se}_{\text {fert }}$ concentration in the straw was $219 \mu \mathrm{g} \mathrm{kg}^{-1}$. At each time point, $\mathrm{KH}_{2} \mathrm{PO}_{4}$-extractable soil ${ }^{77} \mathrm{Se}_{\text {fert }}$ was determined according to the method developed by Zhao and McGrath (1994) for sulphate extraction, which was later adapted by Martens and Suarez (1997) for Se extraction. The extractable soil Se was solubilised by suspending
$3.0 \mathrm{~g}( \pm 0.3 \mathrm{~g})$ of air-dried $<2 \mathrm{~mm}$ sieved soil in $9 \mathrm{~mL}$ $0.016 \mathrm{M} \mathrm{KH}_{2} \mathrm{PO}_{4}$ in $50 \mathrm{~mL}$ polypropylene centrifuge tubes and shaking end-over-end for $1 \mathrm{~h}$ at $27 \mathrm{rpm}$. Soil solutions were centrifuged at $2200 \mathrm{~g}$ for $20 \mathrm{~min}$ and filtered to $<0.22 \mu \mathrm{m}$ using a Millex syringe driven filter unit and stored in ICP tubes, at room temperature, in the dark, pending elemental and speciation analysis, without dilution, by ICP-MS and LC-ICP-MS.

The half-life of the fixation of ${ }^{77} \mathrm{Se}$ released by decomposition of the enriched straw, at each rate of straw addition $(200,500$ and $1000 \mathrm{mg}$ ) was calculated from Eq. 1,

$S e_{t}=S e_{0} e^{-k t}$

where $\mathrm{Se}_{\mathrm{t}}$ is the concentration of extractable ${ }^{77} \mathrm{Se}_{\mathrm{P}}$ at time $\mathrm{t}\left(\mu \mathrm{g} \mathrm{kg}^{-1}\right), \mathrm{Se}_{0}$ is the initial concentration of extractable ${ }^{77} \mathrm{Se}_{\text {fert }}$ present following addition of straw to the soil, $\mathrm{k}$ is the reaction rate constant $\left(\mathrm{d}^{-1}\right)$ and $\mathrm{t}$ is time (d).

The potential increase in soil ${ }^{77} \mathrm{Se}$ at each site from the incorporation of ${ }^{77} \mathrm{Se}$-enriched crop residues (wheat straw) during ploughing after $\mathrm{H} 1$ and the subsequent release of ${ }^{77} \mathrm{Se}$ by microbially driven straw decomposition was calculated using Eq. 2.

$\Delta^{77} \operatorname{Se}_{s}={ }^{77} \operatorname{Se}_{S T} \times\left(\frac{\left(\frac{Y_{S T} \times Y_{p R}}{100-Y_{p R}}\right)}{W s \times 1000}\right)$

Where, $\Delta^{77} \mathrm{Se}_{\mathrm{S}}$ is the concentration increase of soil ${ }^{77} \mathrm{Se}\left(\mu \mathrm{g} \mathrm{kg}^{-1}\right),{ }^{77} \mathrm{Se}_{\mathrm{ST}}$ is the concentration of ${ }^{77} \mathrm{Se}_{\text {fert }}$ in the straw $\left(\mu \mathrm{g} \mathrm{kg}^{-1}\right), \mathrm{Y}_{\mathrm{ST}}$ is the recovered yield of straw per plot $\left(\mathrm{g} \mathrm{m}^{2}\right), \mathrm{Y}_{\mathrm{pR}}$ is the proportion (\%) of $\mathrm{Y}_{\mathrm{ST}}$ which is not harvested at $\mathrm{H} 1$ (crop residue, estimated at $22 \%$ for winter wheat by Zajacc et al. 2013) and $\mathrm{W}_{\mathrm{S}}$ is the weight of soil per plot $\left(250 \mathrm{~kg} \mathrm{~m}^{2}\right.$, assuming a bulk density of $2500 \mathrm{tha}^{-1}$ ).

Kinetics of selenate reaction with soil

The equivalent of $1500 \mathrm{~g} \mathrm{DW},<4 \mathrm{~mm}$ sieved, field moist topsoil from the DH and NEW sites, was spiked with a stock solution of ${ }^{77} \mathrm{Se}^{\mathrm{VI}}$ at a rate of $16 \mu \mathrm{g} \mathrm{kg}^{-1}$ of soil and gently mixed with a food mixer, to ensure thorough mixing of the ${ }^{77} \mathrm{Se}^{\mathrm{VI}}$ spike solution with the soil. Spiked soils were split equally into three replicate $1 \mathrm{~L}$ glass Duran bottles (500 g DW soil in each bottle), and 
incubated at $10{ }^{\circ} \mathrm{C}$ (Model MIR-254, Sanyo) in the dark. Sequential extractions were performed (at pre-determined incubation time points) on $5 \mathrm{~g}$ ( \pm $0.1 \mathrm{~g})$ spiked soil, with $0.01 \mathrm{M} \mathrm{Ca}\left(\mathrm{NO}_{3}\right)_{2}$ and $0.016 \mathrm{M} \mathrm{KH}_{2} \mathrm{PO}_{4}$ in a temperature-controlled room at $10{ }^{\circ} \mathrm{C}$; the sum of which was defined as labile ${ }^{77} \mathrm{Se}$. Calcium nitrate extractable soil $\mathrm{Se}$ was solubilised by suspending $3.0 \mathrm{~g}( \pm 0.3 \mathrm{~g})$ of airdried $<2 \mathrm{~mm}$ sieved soil in $20 \mathrm{~mL} 0.01 \mathrm{M}$ $\mathrm{Ca}\left(\mathrm{NO}_{3}\right)_{2}$ in $50 \mathrm{~mL}$ polypropylene centrifuge tubes and shaking end-over-end for $1 \mathrm{~h}$ at $27 \mathrm{rpm}$. Suspensions were filtered to $<0.22 \mu \mathrm{m}$ using a Millex syringe driven filter unit and pipetted $(1.5 \mathrm{~mL})$ into HPLC vials, for immediate speciation analysis, without dilution, by LC-ICP-MS. 'Adsorbed' ${ }^{77} \mathrm{Se}$ was then solubilised by re-suspending the soil in $9 \mathrm{~mL} 0.016 \mathrm{M} \mathrm{KH}_{2} \mathrm{PO}_{4}$ in $50 \mathrm{~mL}$ polypropylene centrifuge tubes and shaking end-over-end for $1 \mathrm{~h}$ at $27 \mathrm{rpm}$. Soil solutions were centrifuged at $2200 \mathrm{rpm}$ for $20 \mathrm{~min}$ and syringe-filtered to $<0.22 \mu \mathrm{m}$. The proportion of ${ }^{77} \mathrm{Se}_{\text {fert }}$ from the spike that was fixed in the soil was determined by subtracting the concentration of labile ${ }^{77} \mathrm{Se}_{\text {fert }}$ (sum of the ${ }^{77} \mathrm{Se}_{\text {fert }}$ from the spike in calcium nitrate and phosphate extractions) from the concentration of ${ }^{77} \mathrm{Se}^{\mathrm{VI}}$ initially added to the system (16 $\mu \mathrm{g} \mathrm{kg}^{-1}$ soil).

\section{Selenium isotope analysis}

Determination of residual ${ }^{77} \mathrm{Se}_{\text {fert }}$ in soils was initially attempted following $\mathrm{HNO}_{3}-\mathrm{HClO}_{4}$ - $\mathrm{HF}$ digestion, however the dilution of digests required for ICP-MS analysis (2.5 $\mathrm{L} \mathrm{g}^{-1}$ of soil), and the levels of interference encountered, were too great to enable discrimination of applied ${ }^{77} \mathrm{Se}$ against background. Therefore, residual ${ }^{77} \mathrm{Se}_{\text {fert }}$ in soils was determined following extraction with $10 \%$ tetra methyl ammonium hydroxide (TMAH), according to the method developed by Watts and Mitchell (2009) for determination of total soil iodine concentration. TMAHextractable soil Se was solubilised by suspending $1.0 \mathrm{~g}( \pm 0.1 \mathrm{~g})$ of air-dried $<2 \mathrm{~mm}$ sieved soil in $10 \mathrm{~mL} 10 \%$ TMAH in $50 \mathrm{~mL}$ polypropylene centrifuge tubes and heating to $70{ }^{\circ} \mathrm{C}$ for $3 \mathrm{~h}$ in an oven (Scientific Laboratory Supplies Ltd). Milli-Q water $(5 \mathrm{~mL})$ was added and the soil suspensions were centrifuged at $2200 \mathrm{~g}$ for $20 \mathrm{~min}$. The resulting supernatant solution was diluted to $1 \% \mathrm{TMAH}$ with
Milli-Q water to produce an effective soil:solution $(w / v)$ ratio of $1: 100$ prior to analysis by ICP-MS. Soil nickel (Ni) and germanium $(\mathrm{Ge})$ content were also determined in these extractions to help assess a possible interference at $\mathrm{m} / \mathrm{z} .77$ from the polyatomic species ${ }^{60} \mathrm{Ni}^{16} \mathrm{O}^{1} \mathrm{H}$ and the hydride ${ }^{76} \mathrm{Ge}^{1} \mathrm{H}$.

Total Se content of straw, chaff and grain was determined on oven-dried plant material (at $30^{\circ} \mathrm{C}$ ) after grinding in an ultra-centrifugal mill fitted with a $0.5 \mathrm{~mm}$ titanium screen. Approximately $0.2 \mathrm{~g}$ ( \pm $0.02 \mathrm{~g}$ ) of oven-dried, milled material was suspended in $6 \mathrm{~mL} 70 \% \mathrm{HNO}_{3}$ in pressurised PFA vessels and digested via microwave heating (Model Multiwave 3000 fitted with a 48-place rotor; Anton Paar). Digested samples were diluted to $20 \mathrm{~mL}$ with Milli-Q water for storage and further diluted to $2 \% \mathrm{HNO}_{3}$ prior to analysis by ICP-MS.

\section{Elemental analysis}

Elemental analysis was undertaken on an ICP-MS (X-Series ${ }^{\text {II }}$, Themo Fisher Scientific). Samples were introduced at $1 \mathrm{~mL} \mathrm{~min}{ }^{-1}$ through a concentric glass venturi nebuliser and peltier-cooled $\left(3^{\circ} \mathrm{C}\right)$ spray chamber. Instrumental drift was corrected using internal standards $\left({ }^{72} \mathrm{Ge},{ }^{103} \mathrm{Rh}\right.$ and $\left.{ }^{185} \mathrm{Re}\right)$. A hydrogen collision-reaction cell $\left(\mathrm{H}_{2}\right.$-cell $)$ was used to reduce interference from polyatomic species during Se analysis (e.g. ${ }^{38} \mathrm{Ar}-{ }^{40} \mathrm{Ar}$ interference with ${ }^{78} \mathrm{Se}$ ). For analysis of ${ }^{77} \mathrm{Se}$ enriched samples, Ge was not used as an internal standard due to the interference at mass 77 caused by ${ }^{76} \mathrm{Ge}$ hydride formation $\left({ }^{76} \mathrm{Ge}\right.$ natural abundance $7.76 \%$ ). Methanol (c. $4 \%$ ) was added to all samples to increase the ionisation efficiency of Se in the plasma. Selenium speciation analysis of $\mathrm{KH}_{2} \mathrm{PO}_{4}$ soil extractions $\left({ }^{77} \mathrm{Se}^{\mathrm{IV}}\right.$ and ${ }^{77} \mathrm{Se}^{\mathrm{VI}}$ ) was undertaken by LC-ICP-MS following in-line chromatographic separation (Dionex Model ICS-3000) in isocratic mode with a Hamilton PRP-X100 anion exchange column $(250 \times 4.6 \mathrm{~mm} ; 5 \mu \mathrm{m}$ particle size $)$ fitted with a guard column (PEEK, PRP X-100). The mobile phase (flow rate $1.3 \mathrm{~mL} \mathrm{~min}^{-1}$ ) was $50 \mathrm{mmol}$ $\mathrm{L}^{-1} \mathrm{NH}_{4} \mathrm{NO}_{3}, 1 \times 10^{-5} \mathrm{~mol} \mathrm{~L}{ }^{-1} \mathrm{Na}_{2}$-EDTA, $2 \%$ b.v. methanol with $\mathrm{pH}$ adjusted to 9.4 with Tris buffer. Sample processing was undertaken using PlasmaLab software with peaks of individual species manually integrated. A standard was analysed after every six samples to enable correction for instrumental drift by linear interpolation. 
Data processing and quantification of selenium-77 enrichment

Raw intensity data were exported as 'counts-per-second' (cps) values at $m / z, 77$ and 78 corrected for blanks values and drift. The ${ }^{78}(\mathrm{~m} / \mathrm{z})$ signal was first corrected for hydride formation $\left({ }^{77} \mathrm{SeH}\right)$. When measuring $\mathrm{Se}$ isotopes by ICP-MS in $\mathrm{H}_{2}$-cell mode, formation of $\mathrm{Se}$ hydride (SeH) occurs. This is irrelevant to Se analysis if the isotopic abundances of standards and samples are identical but a possible source of error when working with non-standard isotopic abundances. In the case of ${ }^{77} \mathrm{Se}$, the ${ }^{77}(\mathrm{~m} / \mathrm{z})$ signal is therefore subject to loss from the formation of ${ }^{77} \mathrm{SeH}^{+}$, which in turn increases the ${ }^{78}(\mathrm{~m} / \mathrm{z})$ signal, and also gain from the formation of ${ }^{76} \mathrm{SeH}^{+}$. The contribution from ${ }^{76} \mathrm{SeH}^{+}$to the ${ }^{77}(\mathrm{~m} / \mathrm{z})$ signal was quantified after the ${ }^{78}(\mathrm{~m} / \mathrm{z})$ signal was corrected for ${ }^{77} \mathrm{SeH}^{+}$formation because the ${ }^{76}(\mathrm{~m} / \mathrm{z})$ signal was inferred from the corrected ${ }^{78}(\mathrm{~m} / \mathrm{z})$ signal on the basis of expected background isotopic ratios. The contribution of ${ }^{77} \mathrm{SeH}^{+}$to the ${ }^{78}(\mathrm{~m} / \mathrm{z})$ signal was established by analysing pure ${ }^{77} \mathrm{Se}$ standards (c. $100 \%$ isotope abundance) and calculating the ratio of ${ }^{77} \mathrm{SeH}^{+}$(reported as ${ }^{78} \mathrm{~m} / \mathrm{z}$ ) to ${ }^{77} \mathrm{Se}$ (reported as ${ }^{77} \mathrm{~m} / \mathrm{z}$ ) using Eq. 3:

$H r=\frac{78(m / z)}{77(m / z)}$

where, Hr is the hydride ratio and ${ }^{78}(\mathrm{~m} / \mathrm{z})$ and ${ }^{77}(\mathrm{~m} / \mathrm{z})$ are the signals (cps) measured in the pure ${ }^{77} \mathrm{Se}$ standard. The ${ }^{78}(\mathrm{~m} / \mathrm{z})$ signal in samples was corrected for ${ }^{77} \mathrm{SeH}^{+}$ production, arising from the (enriched) ${ }^{77}$ Se spike, using an approximate solution shown in Eq. 4:

${ }^{78} S e_{c p s}=\left[{ }^{78}\left(m^{m} / z\right)-\left({ }^{77}(m / z) \times H_{r}\right)\right]\left(1+\frac{H_{r}{ }^{78} S e_{i a}}{{ }^{78} S e_{i a}}\right)$

where ${ }^{78} \mathrm{Se}_{\mathrm{cps}}$ is the corrected ${ }^{78}(\mathrm{~m} / \mathrm{z})$ signal and ${ }^{77} \mathrm{Se}_{\mathrm{ia}}$ and ${ }^{78} \mathrm{Se}_{\mathrm{ia}}$ are the naturally occurring isotopic abundances of ${ }^{77} \mathrm{Se}$ and ${ }^{78} \mathrm{Se}$ respectively.

The ${ }^{76} \mathrm{Se}$ signal $\left({ }^{76} \mathrm{Se}_{\mathrm{cps}}\right)$ was then inferred from ${ }^{78} \mathrm{Se}_{\mathrm{cps}}$ on the basis of the natural isotopic ratio ${ }^{76} \mathrm{Se}_{\mathrm{ia}} \cdot{ }^{78} \mathrm{Se}_{\mathrm{ia}}$ using Eq. 5. However, values of ${ }^{76} \mathrm{Se}_{\mathrm{cps}}$ are slightly overestimated due to the greater sensitivity of ${ }^{78} \mathrm{Se}$, therefore a mass discrimination factor (MDF, calculated in Eq. 6) must also be applied to correct for this:
${ }^{76} \mathrm{Se}_{c p s}={ }^{78} \mathrm{~S} e_{c p s}\left(\frac{{ }^{76} \mathrm{~S} e_{i a}}{{ }^{78} S e_{i a}}\right) \times M D F$

where, ${ }^{76} \mathrm{Se}_{\mathrm{ia}}$ is the isotopic abundance of ${ }^{76} \mathrm{Se}$. The signal for native ${ }^{77} \mathrm{Se}_{\mathrm{cps}}$ was also calculated in this manner.

$M D F=1-[(1-0.9577) \times 2]$

In Eq. 6, the value 0.9577 is the MDF per mass unit, determined from analysis of a normal multi-isotope calibration standard, which is multiplied by a mass difference of 2 (78-76).

It is reasonable to assume that the extent of hydride formation is similar for all Se isotopes (Nelms, S. Thermo Scientific, personal communication) therefore the ${ }^{77}\left(\mathrm{~m} / \mathrm{z}\right.$ ) signal was also corrected for ${ }^{76} \mathrm{SeH}^{+}$formation and converted to represent the total ${ }^{77} \mathrm{Se}$ concentration $\left({ }^{77} \mathrm{Se}_{\text {tot }}\right.$ expressed in $\left.\mu \mathrm{g} \mathrm{L}^{-1}\right)$ using Eq. 7:

${ }^{77} \mathrm{~S} e_{t o t}=\frac{\left({ }^{77}(m / z)-{ }^{76} \mathrm{~S} e_{c p s} \times H_{r}\right)}{{ }^{77} \mathrm{~S} e_{\text {sen }}}$

Where, ${ }^{77} \mathrm{Se}_{\mathrm{sen}}$ is the measured sensitivity of ${ }^{77} \mathrm{Se}$ expressed in $\mathrm{cps} \mathrm{ppb}^{-1}$.

The concentration of ${ }^{77} \mathrm{Se}_{\text {tot }}$ represents all ${ }^{77} \mathrm{Se}$ in an extract, from both native and added ${ }^{77} \mathrm{Se}$. In order to establish the concentration of ${ }^{77} \mathrm{Se}$, which was from the enriched isotope fertilizer, the native ${ }^{77} \mathrm{Se}$ concentration present $\left({ }^{77} \mathrm{Se}_{\mathrm{N}}, \mu \mathrm{g} \mathrm{L}^{-1}\right)$ was calculated first, using Eq. 8:

${ }^{77} \mathrm{~S} e_{N}=\frac{\left({ }^{77} \mathrm{~S} e_{N, c p s}{ }^{76} \mathrm{~S} e_{c p s} \times H_{r}\right)}{S e_{s e n}}$

Where, ${ }^{77} \mathrm{Se}_{\mathrm{N}, \mathrm{cps}}$ is the native ${ }^{77} \mathrm{Se}$ signal inferred from the ${ }^{78} \mathrm{Se}_{\mathrm{cps}}$ signal, on the basis of natural isotopic abundance.

The concentration of ${ }^{77} \mathrm{Se}$ from addition of enriched ${ }^{77} \mathrm{Se}$ isotope $\left({ }^{77} \mathrm{Se}_{\text {fert }}\right)$ was then calculated using Eq. 9:

${ }^{77} \mathrm{~S} e_{\text {fert }}={ }^{77} \mathrm{~S} e_{\text {tot }}{ }^{-{ }^{77}} \mathrm{~S} e_{N}$

The concentration of ${ }^{77} \mathrm{Se}_{\text {fert }}\left(\mu \mathrm{g} \mathrm{L}{ }^{-1}\right)$ was then converted to a gravimetric basis $\left(\mu \mathrm{g} \mathrm{kg}^{-1}\right)$ for individual samples of soil or plant material.

Rainfall data

Rainfall data were obtained from the University of Nottingham, School of Biosciences, weather station (grid 
ref.: $\left.52^{\circ} 50^{\prime} 11.34^{\prime \prime} \mathrm{N}-1^{\circ} 15^{\prime} 04.25^{\prime \prime} \mathrm{W}\right)$ operated in partnership with the Met Office (metoffice.gov.uk).

Statistical analysis

Paired T-tests were performed in Minitab (version 16.2.2) and Duncan's multiple range test was performed in ANOVA Options within Genstat (version 15.1.0.8035).

\section{Results}

\section{Soil characteristics}

Soil characteristics for the three field sites are shown in Table 1. The DH and WOR topsoil samples were both clay loams and the NEW topsoil was a sandy clay loam. Soil $\mathrm{pH}$ was similar in the DH and WOR topsoils (7.29 and 7.34, respectively) but lower in the NEW topsoil (6.95). Soil organic carbon (SOC) content was similar in the NEW and WOR topsoils (1.03 and $1.01 \%$, respectively) but approximately double in the $\mathrm{DH}$ topsoil (2.07\%). Manganese oxide concentration was lowest in the NEW topsoil and was approximately half that of the WOR topsoil (1.36 and $2.66 \mathrm{~g} \mathrm{~kg}^{-1}$, respectively), which was the greatest. Aluminium oxide concentration was comparable in the DH and WOR topsoils $(0.460$ and $0.475 \mathrm{~g} \mathrm{~kg}^{-1}$ ), but greatest in the NEW topsoil $\left(0.527 \mathrm{~g} \mathrm{~kg}^{-1}\right)$. Olsen phosphate concentration was highly variable between the three topsoils, with $16.5 \mathrm{mg} \mathrm{kg}^{-1}$ in the WOR, $37.5 \mathrm{mg} \mathrm{kg}^{-1}$ in NEW and $70.1 \mathrm{mg} \mathrm{kg}^{-1}$ in DH topsoil.

Selenium-77 recovery at first harvest (H1)

Based on harvest from the central $1.0 \mathrm{~m}^{2}$ from each plot, grain yields were 8.6, 8.5 and $9.7 \mathrm{tha}^{-1}$ for $\mathrm{DH}$, NEW and WOR sites respectively; corresponding straw yields were 13.6, 11.1 and $12.0 \mathrm{t} \mathrm{ha}^{-1}$. Recovery of applied ${ }^{77} \mathrm{Se}\left({ }^{77} \mathrm{Se}_{\text {fert }}\right)$ in wheat grain at H1 (Fig. 1a) was comparable across treatment sites (DH 12.4\%; NEW 11.9\%; WOR $15.2 \%$ ). Addition of $10 \mathrm{~g}^{77} \mathrm{Se}^{\mathrm{VI}} \mathrm{ha}^{-1}$ was sufficient to boost total grain Se concentration to 4-13 times that of controls (Table 2). Recovery of ${ }^{77} \mathrm{Se}_{\text {fert }}$ in wheat straw (Fig. 1a) was marginally greater than recovery in wheat grain at the NEW and WOR sites but substantially greater at the DH site (29.7\% in straw; $12.4 \%$ in grain). Recovery of ${ }^{77} \mathrm{Se}_{\text {fert }}$ in wheat chaff (Fig. 1a) was very small at all treatment sites $(<2.5 \%)$. Total recovery in the crop (sum of grain, straw and chaff) varied between all sites (DH 44.5\%; NEW 25.9\%; WOR 33.0\%) with differences in recovery in the straw being the major discriminator. Retention of ${ }^{77} \mathrm{Se}_{\text {fert }}$ in topsoil was observed at all treatment sites (Fig. 1a) but varied between sites (DH 15.0\%; NEW 30.9\%; WOR 20.5\%), whereas recovery in subsoils was small and comparable between sites (DH 3.57\%; NEW 2.62\%; WOR 3.49\%). Apparent losses of ${ }^{77} \mathrm{Se}_{\text {fert }}$ from the system (Fig. 1a) were similar across all sites (DH 36.9\%; NEW 40.6\%; WOR 43.0\%).

The concentration of native soil $\mathrm{Se}\left(\mathrm{Se}_{\mathrm{N}}\right)$ in the crop was greatest in the straw at all treatment sites (Fig. 1b). Crop partitioning of $\mathrm{Se}_{\mathrm{N}}$ followed broadly the same pattern as ${ }^{77} \mathrm{Se}_{\text {fert }}$ (Fig. 1a) despite differences in the timing of supply. The contribution of native soil Se to total Se in the crop was comparable (within 5\%) between crop fractions at each site, none of which exceeded $25 \%$; the majority ( $>75 \%$ ) of Se in each crop fraction originated from application of ${ }^{77} \mathrm{Se}_{\text {fert }}$. The concentration and contribution of native soil ${ }^{77} \mathrm{Se}\left({ }^{77} \mathrm{Se}_{\mathrm{N}}\right)$ to each crop fraction was greatest at the $\mathrm{DH}$ site and lowest at the WOR site (Fig. 1b).

\section{Retention of selenium-77 in soil}

All topsoil samples from ${ }^{77} \mathrm{Se}$-treated plots showed an increase in the raw ${ }^{77}(\mathrm{~m} / \mathrm{z}):{ }^{78}(\mathrm{~m} / \mathrm{z})$ ratio above that of the field control topsoil and therefore measureable concentrations of residual ${ }^{77} \mathrm{Se}_{\text {fert }}$ (Fig. 2). This increase persisted across the three topsoil sampling events at harvest in the year of ${ }^{77} \mathrm{Se}$ application (H1), the following spring (S2) and at the end of the following growing season (H2). All sampled subsoils, with the exception of the WOR subsoil sampled in 2013, showed only marginal concentrations of ${ }^{77} \mathrm{Se}_{\text {fert }}$ above that of the field control topsoil. The DH and NEW field control soils exhibited very similar raw ${ }^{77}(\mathrm{~m} / \mathrm{z}):{ }^{78}(\mathrm{~m} / \mathrm{z})$ ratios $(0.335$ and 0.333 , respectively), whereas the ratio in the WOR control soil was greater $(0.343)$. However, the WOR control soil also exhibited an apparent measureable concentration of ${ }^{77} \mathrm{Se}_{\text {fert }}$ (Fig. 2). Coincidentally, during transition through the ICP-MS, the combined effect of hydride generation, which acts to increase the apparent ${ }^{77}(\mathrm{~m} / \mathrm{z}):{ }^{78}(\mathrm{~m} / \mathrm{z})$ ratio, and mass discrimination which has the opposite effect, almost cancelled each other out. 
Table 1 Soil properties at each site

\begin{tabular}{|c|c|c|c|c|c|c|c|c|c|c|c|c|}
\hline Site & & $\mathrm{pH}$ & $\begin{array}{l}\text { Org C } \\
(\%)\end{array}$ & $\begin{array}{l}\mathrm{Fe}_{2} \mathrm{O}_{3}{ }^{*} \\
\left(\mathrm{~g} \mathrm{~kg}^{-1}\right)\end{array}$ & $\begin{array}{l}\mathrm{MnO}_{2}{ }^{*} \\
\left(\mathrm{~g} \mathrm{~kg}^{-1}\right)\end{array}$ & $\begin{array}{l}\mathrm{Al}(\mathrm{OH})_{3}{ }^{*} \\
\left(\mathrm{~g} \mathrm{~kg}^{-1}\right)\end{array}$ & $\begin{array}{l}\text { Sand } \\
(\%)\end{array}$ & $\begin{array}{l}\text { Silt } \\
(\%)\end{array}$ & $\begin{array}{l}\text { Clay } \\
(\%)\end{array}$ & $\begin{array}{l}\text { Avail. P } \\
\left(\mathrm{mg} \mathrm{kg}^{-1}\right)\end{array}$ & $\begin{array}{l}\text { Total Soil Se } \\
\left(\mu \mathrm{g} \mathrm{kg}^{-1}\right)\end{array}$ & $\begin{array}{l}\text { TMAH Ext. Soil Se } \\
\left(\mu \mathrm{g} \mathrm{kg}^{-1}\right)\end{array}$ \\
\hline \multirow[t]{2}{*}{ Dunnington Heath (DH) } & Topsoil & 7.29 & 2.07 & 11.5 & 2.15 & 0.460 & 34.5 & 35.7 & 29.8 & 70.1 & 372 & 209 \\
\hline & Subsoil & 7.46 & 0.518 & - & - & - & - & - & - & 11.1 & 373 & 194 \\
\hline \multirow[t]{2}{*}{ Newport (NEW) } & Topsoil & 6.95 & 1.03 & 29.3 & 1.36 & 0.527 & 50.2 & 21.8 & 28.1 & 37.5 & 403 & 216 \\
\hline & Subsoil & 7.16 & 0.388 & - & - & - & - & - & - & 1.43 & 404 & 207 \\
\hline \multirow[t]{2}{*}{ Worcester (WOR) } & Topsoil & 7.34 & 1.01 & 12.4 & 2.66 & 0.475 & 27.9 & 34.5 & 37.6 & 16.5 & 374 & 165 \\
\hline & Subsoil & 7.50 & 0.594 & - & - & - & - & - & - & 4.12 & 373 & 147 \\
\hline
\end{tabular}

Values are means of the four sub-plots established at each site

*Extractable with dithionite-citrate-bicarbonate reagent

Residual selenium-77 in crops

Crop rotation occurred at the NEW and WOR sites after H1 (wheat): maize and oilseed rape were sown in September 2012 at the NEW and WOR sites, respectively, whereas winter wheat was re-sown at the DH site. Negligible concentrations of ${ }^{77} \mathrm{Se}_{\text {fert }}$ were detected in crop straw at $\mathrm{H} 2$ at all sites, compared to wheat straw at H1 (Table 3).

Fixation of selenium-77 in soil

The time-dependent fixation of selenate $\left({ }^{77} \mathrm{Se}^{\mathrm{VI}} ; 16 \mu \mathrm{g}\right.$ $\mathrm{kg}^{-1}$ ) incubated with soils from the DH and NEW sites is shown in Fig. 3. 'Fixed' $\mathrm{Se}\left({ }^{77} \mathrm{Se}^{\mathrm{VI}}{ }_{\text {Fixed }}\right)$ was calculated as the difference between the initial addition of selenate and the measured concentrations of inorganic $\mathrm{Se}^{\mathrm{IV}}$ and $\mathrm{Se}^{\mathrm{VI}}$ in a two-stage extraction with $0.01 \mathrm{M}$ $\mathrm{Ca}\left(\mathrm{NO}_{3}\right)_{2}$ and $0.016 \mathrm{KH}_{2} \mathrm{PO}_{4}$ solutions. There was clear evidence of reduction to selenite from the added selenate $\left(16 \mu \mathrm{g} \mathrm{kg}^{-1}\right)$ with ${ }^{77} \mathrm{Se}^{\mathrm{IV}}$ concentrations ranging from $0.03-0.42 \mu \mathrm{g} \mathrm{kg}^{-1}$ and $0.03-0.54 \mu \mathrm{g} \mathrm{kg}^{-1}$ in phosphate extractions of the DH and NEW topsoils respectively. The fixed Se was assumed to be mainly bound to humus. The fixation rate was approximately $0.1 \mu \mathrm{g} \mathrm{kg}^{-1}$ $\mathrm{d}^{-1}$ in both soils so that $80 \%$ was fixed after 160 days.

Release of selenium-77 to soil from straw decomposition

The concentrations of labelled selenate $\left({ }^{77} \mathrm{Se}^{\mathrm{VI}}{ }_{\text {fert }}\right)$ and total ${ }^{77} \mathrm{Se}_{\text {fert }}$, extractable by phosphate $(0.016 \mathrm{M})$ from

${ }^{77} \mathrm{Se}$-enriched straw, incubated in moist soil, were positively correlated with straw application rate and all decreased steadily throughout the time of incubation (30 days) following an irreversible first order decay trend (Fig. 4a; b) due to fixation in the soil. The average proportion of ${ }^{77} \mathrm{Se}_{\text {fert }}$ released from the soil-incubated enriched straw that was present as selenate $\left({ }^{77} \mathrm{Se}^{\mathrm{VI}}\right.$ fert $)$ increased with the level of straw application to 13.4, 45.7 and $48.7 \%$ of ${ }^{77} \mathrm{Se}_{\text {fert }}$ for straw additions of 200 , 500 and $1000 \mathrm{mg}$ per $5 \mathrm{~g}$ field moist soil respectively. The concentration of labelled selenite $\left({ }^{77} \mathrm{Se}^{\mathrm{IV}}\right.$ fert , not shown) released from ${ }^{77} \mathrm{Se}$-enriched straw was negligible $\left(<1 \mu \mathrm{g} \mathrm{kg} \mathrm{soil}{ }^{-1}\right)$ across all straw application levels, throughout the time of incubation (30 days).

\section{Discussion}

Recovery of ${ }^{77} \mathrm{Se}_{\text {fert }}$ at harvest 2012

The recovery of ${ }^{77} \mathrm{Se}_{\text {fert }}$ at $\mathrm{H} 1$ in wheat grain (Fig. 1a) was comparable to previous studies comparing Se treatments with controls. Broadley et al. (2010) applied $\mathrm{Se}^{\mathrm{VI}}$ in liquid form $\left(\mathrm{as}_{2} \mathrm{SeO}_{4}\right)$ at six different application rates (in the range 5-100 $\mathrm{g} \mathrm{ha}^{-1}$ ) to wheat at four sites in the UK and reported a Se recovery range of 10.1 to $17.3 \%$ in the grain. Lyons et al. (2004) and Curtin et al. (2008) reported average recovery of $\mathrm{Se}^{\mathrm{VI}}$ (added as $\mathrm{Na}_{2} \mathrm{SeO}_{4}$ ) in Australian wheat grain at $13.5 \%$ and $\mathrm{New}$ Zealand wheat grain at $17.0 \%$, respectively. Chilimba et al. (2012a) reported recovery of $\mathrm{Se}^{\mathrm{VI}}$ (added as $\mathrm{Na}_{2} \mathrm{SeO}_{4}$ ) across successive application years in Malawian maize grain at $16-18 \%$. However, Chilimba et al. (2012b) reported lower recovery levels of ${ }^{74} \mathrm{Se}^{\mathrm{VI}}$ (added 
a

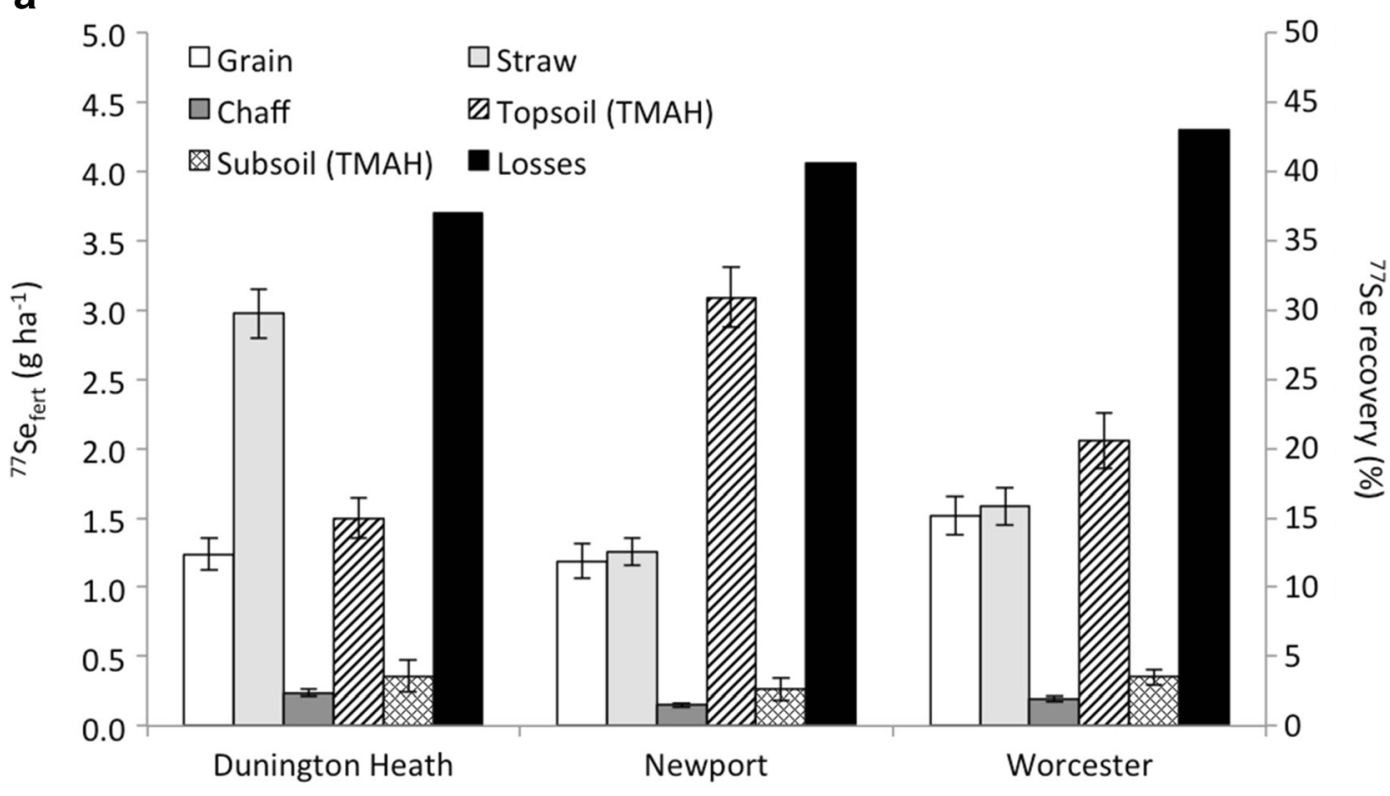

b

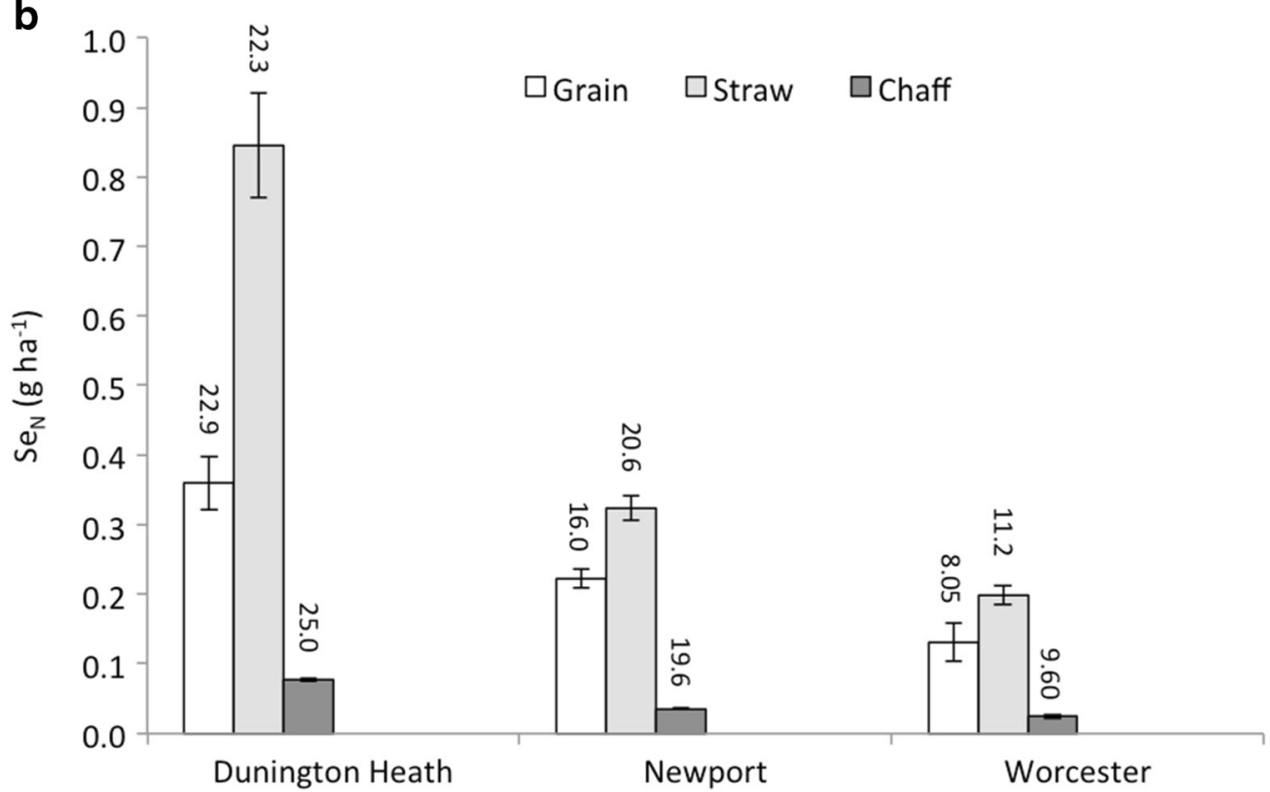

Fig. 1 a Recovery and losses (\% and $\mathrm{g} \mathrm{ha}^{-1}$ ) of ${ }^{77}$ Se from fertiliser application $\left({ }^{77} \mathrm{Se}_{\text {fert }}\right)$ in grain, straw, chaff, topsoil and subsoil, at first harvest $(\mathrm{H} 1)$ (soil concentrations are corrected for control values) and

as $\mathrm{Na}_{2}{ }^{74} \mathrm{SeO}_{4}$ ) in maize grain at $6.5 \%$ and $10.8 \%$ across two treatment sites in Malawi and Stephen et al. (1989) observed 2-6\% recovery of $\mathrm{Se}^{\mathrm{VI}}$ (added as $\mathrm{Na}_{2} \mathrm{SeO}_{4}$ ) in wheat grain in New Zealand, which is in a similar range to results from the long-term Finnish biofortification programme $(<10 \%)$, reported by Eurola (2005). Taking the average daily per-capita b concentration ( $\mathrm{g} \mathrm{ha}^{-1}$ ) and contribution (\% listed above each bar) of native soil $\mathrm{Se}\left(\mathrm{Se}_{\mathrm{N}}\right.$; all isotopes) to total $\mathrm{Se}$ in grain, straw and chaff, at H1. Error bars show the standard error of four replicate analyses

intake of cereal and cereal-based products for the UK population as $110 \mathrm{~g}$ (PHE and FAO 2014), the biofortified wheat grain produced in this study would provide, on average, $19.1 \mu \mathrm{g}$ person ${ }^{-1} \mathrm{~d}^{-1}$ of Se (Table 2), which equates to $25.6 \%$ and $31.9 \%$ of the UK recommended nutrient intake (RNI, BNF 2001), for men and women, respectively. 
Table 2 Comparison between the total Se concentration in grain from controls and ${ }^{77} \mathrm{Se}_{\text {fert }}$-treated crops at first harvest (H1); the proportional increase above natural levels resulting from application of $10 \mathrm{~g} \mathrm{ha}^{-1}{ }^{77} \mathrm{Se}^{\mathrm{VI}}$ (enrichment factor); daily quantity of Se that would be supplied by consuming $110 \mathrm{~g}$ (daily average consumption for adults aged 19-64, PHE \& FAO, 2014) of enriched cereals and cereal-based products; proportion of United Kingdom recommended nutrient intake (RNI; BNF, 2001) values for men and women achieved from average consumption of enriched grain

\begin{tabular}{|c|c|c|c|c|c|c|c|}
\hline \multirow[t]{2}{*}{ Site } & \multicolumn{2}{|c|}{ Se concentration in grain } & \multicolumn{2}{|c|}{ Grain Enrichment Factor } & \multirow{2}{*}{$\begin{array}{l}\text { Daily Se intake supplied } \\
\text { by enriched grain } \\
\left(\mu \mathrm{g} \text { person }{ }^{-1} \mathrm{~d}^{-1}\right)\end{array}$} & \multicolumn{2}{|c|}{ Proportion of UK RNI } \\
\hline & $\begin{array}{l}\text { Controls } \\
\left(\mu \mathrm{kg}^{-1}\right)\end{array}$ & $\begin{array}{l}\text { Treated } \\
\left(\mu \mathrm{g} \mathrm{kg}^{-1}\right)\end{array}$ & Mean & $\begin{array}{l}\text { Standard } \\
\text { Error }\end{array}$ & & $\begin{array}{l}\text { Men } \\
(\%)\end{array}$ & $\begin{array}{l}\text { Women } \\
(\%)\end{array}$ \\
\hline Dunington Heath & 14.5 & 187 & 12.9 & 0.811 & 20.6 & 27.4 & 34.2 \\
\hline Newport & 45.3 & 166 & 3.66 & 0.283 & 18.3 & 20.4 & 30.4 \\
\hline Worcester & 19.2 & 169 & 8.81 & 0.511 & 18.6 & 24.8 & 30.9 \\
\hline
\end{tabular}

Values are means of the four sub-plots established at each site

Recoveries of ${ }^{77} \mathrm{Se}_{\text {fert }}$ in wheat straw and grain were similar at the NEW and WOR sites (Fig. 1a), which exhibited total crop recoveries of 25.1 and $33.0 \%$, respectively. Broadley et al. (2010) reported marginally greater recovery of $\mathrm{Se}$ (applied as aqueous $\mathrm{Na}_{2} \mathrm{SeO}_{4}$ at six different application rates spanning 5 to $100 \mathrm{~g} \mathrm{ha}^{-1}$ ) in winter wheat straw than in grain (mean 13.4 and $12.6 \%$, respectively). The greater recovery of ${ }^{77} \mathrm{Se}_{\text {fert }}$ in wheat straw compared to grain at the DH site, can be attributed to two factors. Firstly, the straw:grain concentration ratio for ${ }^{77} \mathrm{Se}_{\text {fert }}$ was almost double that observed at the NEW and WOR sites (DH 1.53; NEW
0.818; WOR 0.847), suggesting that transfer of inorganic ${ }^{77} \mathrm{Se}^{\mathrm{VI}}$ from the straw to protein- or amino acid-bound Se in the grain may have been restricted. Secondly, the straw:grain yield ratio was also greatest at the DH site (DH 1.60; NEW 1.31; WOR 1.23). The DH site also exhibited the lowest recovery of ${ }^{77} \mathrm{Se}_{\text {fert }}$ in topsoil $(15.4 \%$, less than half that observed at the other two sites, Fig. 1a). At the DH site, the greater recovery of ${ }^{77} \mathrm{Se}_{\text {fert }}$ in the straw and the lower recovery in the topsoil may suggest direct foliar adsorption ${ }^{77} \mathrm{Se}_{\mathrm{fert}}$ at the time of application. Despite irrigating the crop canopy immediately after application of ${ }^{77} \mathrm{Se}$, the dry, warm weather

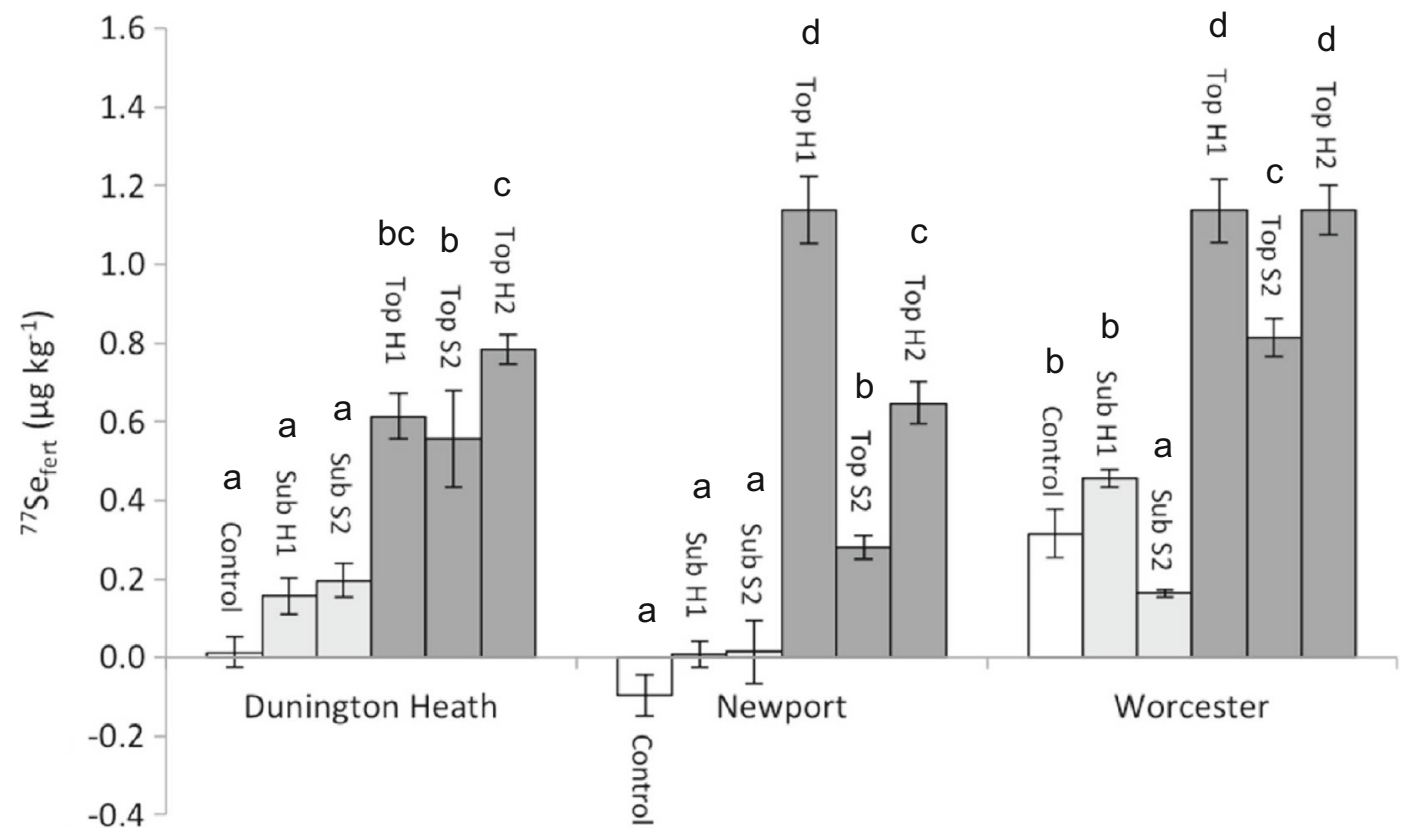

Fig. 2 Concentration $\left(\mu \mathrm{g} \mathrm{kg}^{-1}\right)$ of ${ }^{77} \mathrm{Se}$ from fertiliser application $\left({ }^{77} \mathrm{Se}_{\text {fert }}\right)$ in control soils, subsoils and topsoils at H1, S2 and H2. Letters above bars denote statistically different groups $(p<0.05)$ following Duncan's multiple range test. Error bars show the standard error of four replicate analyses 
Table 3 Concentration of ${ }^{77} \mathrm{Se}_{\text {fert }}$ in wheat straw at first harvest (H1) and crops at second harvest (H2). Crops harvested at $\mathrm{H} 2$ were winter wheat at the Dunnington Heath site, maize at the Worcester site and oilseed rape at the Newport site

\begin{tabular}{lllcc}
\hline Site & $\begin{array}{l}{ }^{77} \mathrm{Se}_{\text {fert }} \text { in } \\
\text { wheat straw }(\mathrm{H} 1) \\
\left(\mu \mathrm{kg}^{-1}\right)\end{array}$ & $\begin{array}{l}\text { Standard } \\
\text { error } \\
\left(\mu \mathrm{g} \mathrm{kg}^{-1}\right)\end{array}$ & $\begin{array}{l}{ }^{77} \mathrm{Se}_{\text {fert }} \text { in } \\
\text { crop straw }(\mathrm{H} 2) \\
\left(\mu \mathrm{kg}^{-1}\right)\end{array}$ & $\begin{array}{l}\text { Standard } \\
\text { error } \\
\left(\mu \mathrm{g} \mathrm{kg}^{-1}\right)\end{array}$ \\
\hline Dunnington Heath & 219 & 14.4 & 3.52 & 0.499 \\
Newport & 113 & 5.37 & 2.46 & 0.827 \\
Worcester & 132 & 9.20 & -2.97 & 0.152 \\
\hline
\end{tabular}

Values are means of the four sub-plots established at each site

conditions at the time of application at the DH site may have contributed to enhanced foliar adsorption of ${ }^{77} \mathrm{Se}_{\text {fert }}$, which was not observed following the heavy rainfall at the time of application at the NEW and WOR sites.

The NEW site exhibited the greatest retention of ${ }^{77} \mathrm{Se}_{\text {fert }}$ in the topsoil (40\%), which had the lowest $\mathrm{pH}$ and the greatest concentration of $\mathrm{Fe}$ and $\mathrm{Al}$ oxides ( $\mathrm{pH}$ 6.95, 29.3 and $0.527 \mathrm{~g} \mathrm{~kg}^{-1}$, respectively, Table 1). Both factors are expected to increase initial retention of ${ }^{77} \mathrm{Se}_{\text {fert }}$ in topsoil through stronger binding to hydrous oxides at lower $\mathrm{pH}$. Furthermore, results from the soil incubation experiment (Fig. 3), showed that the proportion of added ${ }^{77} \mathrm{Se}^{\mathrm{VI}}$ (c. $40 \mathrm{~g} \mathrm{ha}^{-1}$ ) that was fixed in incubated topsoils was approximately $50 \%$ for the DH and NEW sites, 95 days after addition.

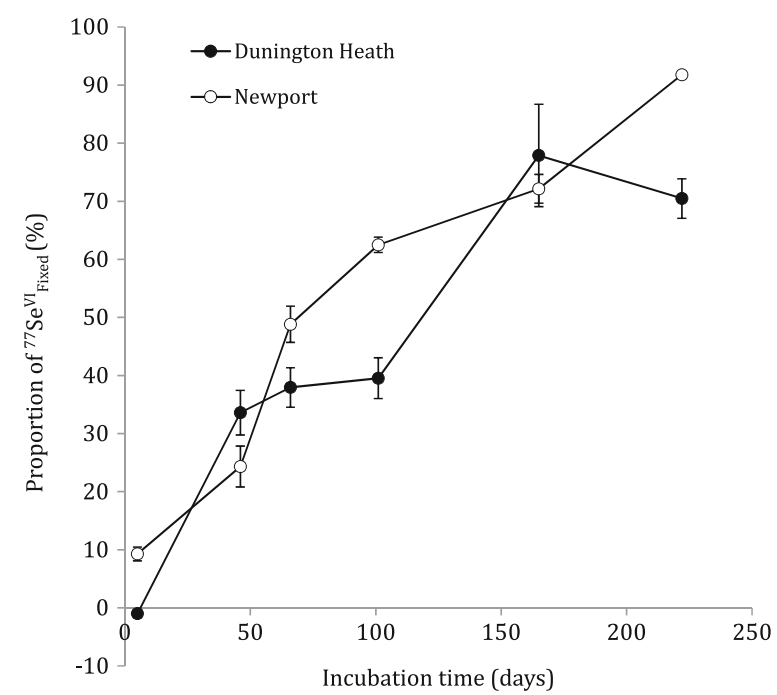

Fig. 3 Proportion (\%) of added ${ }^{77} \mathrm{Se}^{\mathrm{VI}}$ fert that is fixed in soils DH and NEW $\left({ }^{77} \mathrm{Se}^{\mathrm{VI}}{ }_{\text {Fixed }}\right)$ as a function of incubation time; calculated from the proportion (\%) of ${ }^{77} \mathrm{Se}_{\text {fert }}$, added at $16 \mu \mathrm{g} \mathrm{kg}{ }^{-1}$, that remains labile (ie extractable in $0.01 \mathrm{M} \mathrm{Ca}\left(\mathrm{NO}_{3}\right)_{2}$ and $0.016 \mathrm{M}$ $\mathrm{KH}_{2} \mathrm{PO}_{4}$ solutions combined)
Therefore, considering the time elapsed between application of ${ }^{77} \mathrm{Se}^{\mathrm{IV}}$ and first harvest (DH, 93 days; NEW and WOR, 96 days), it is likely that that ${ }^{77} \mathrm{Se}_{\text {fert }}$ retained in topsoil at these sites, would be present in organically bound form or possibly bound within oxides in a form not extractable by phosphate. Certainly Fig. 3 shows that these soils have the capacity to convert most soluble selenate additions to soil, in spring, to fixed forms within a $3-4$ month period.

The relatively small recoveries of ${ }^{77} \mathrm{Se}_{\text {fert }}$ in subsoil $(<4 \%)$ and comparable losses between sites (Fig. 1a) suggests rapid leaching of ${ }^{77} \mathrm{Se}^{\mathrm{VI}}$ after application (c. $40 \%$ of the application), with the remainder being distributed between crop and mainly humus-bound forms in the topsoil. It should also be acknowledged that some of the applied ${ }^{77} \mathrm{Se}^{\mathrm{VI}}$ may have been converted to forms that are not extractable with $10 \%$ TMAH - so retention in topsoil may be underestimated. Leaching losses raise the possibility of a potential toxic hazard. The WHO provisional Se standard for drinking water quality is $40 \mu \mathrm{g} \mathrm{L}^{-1}$, based on an intake (in $2 \mathrm{~L}$ water per day) of $20 \%$ of the upper safe intake level $\left(400 \mu \mathrm{g} \mathrm{day}^{-1}\right.$ of Se) (WHO 2011). It may be assumed that selenate being leached in the soil solution moves initially in a simple piston flow pattern, having mixed with soil pore water in the topsoil $(0-20 \mathrm{~cm})$. Thus, for a soil with a volumetric water content of $40 \%$ at field capacity (c. $800 \mathrm{~m}^{3}$ water in topsoil per hectare), a loss of $40 \%$ Se from an application of $10 \mathrm{~g} \mathrm{ha}^{-1}(4 \mathrm{~g}$ $\mathrm{ha}^{-1}$ ) would produce a solution concentration of $5.0 \mu \mathrm{g} \mathrm{L}^{-1}$. Given further dilution through mixing beyond the field drains it is therefore unlikely that such losses could present a risk to drinking water supplies.

The similar partitioning pattern of native soil Se and ${ }^{77} \mathrm{Se}_{\text {fert }}$ within the crop (Fig. 1a and b), suggests that re- 
a

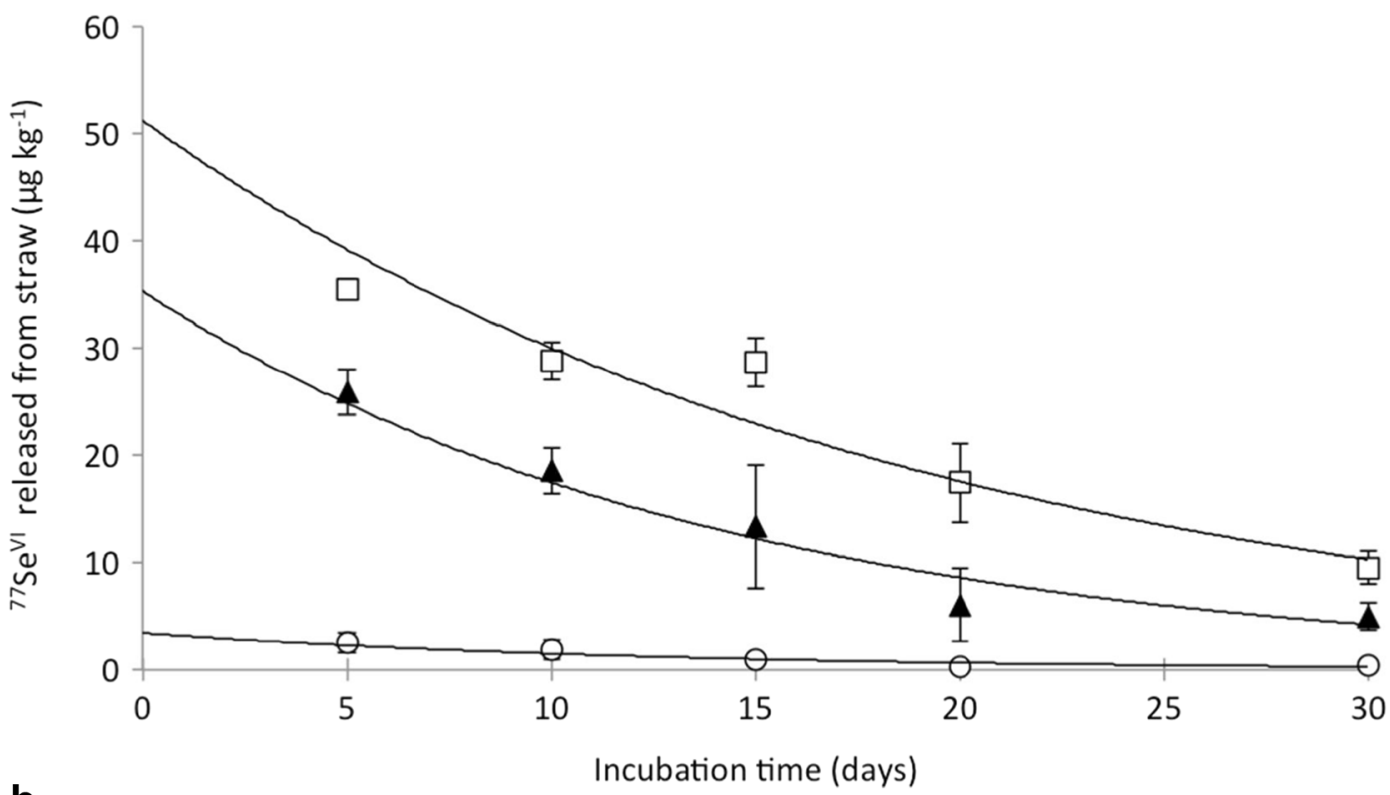

b

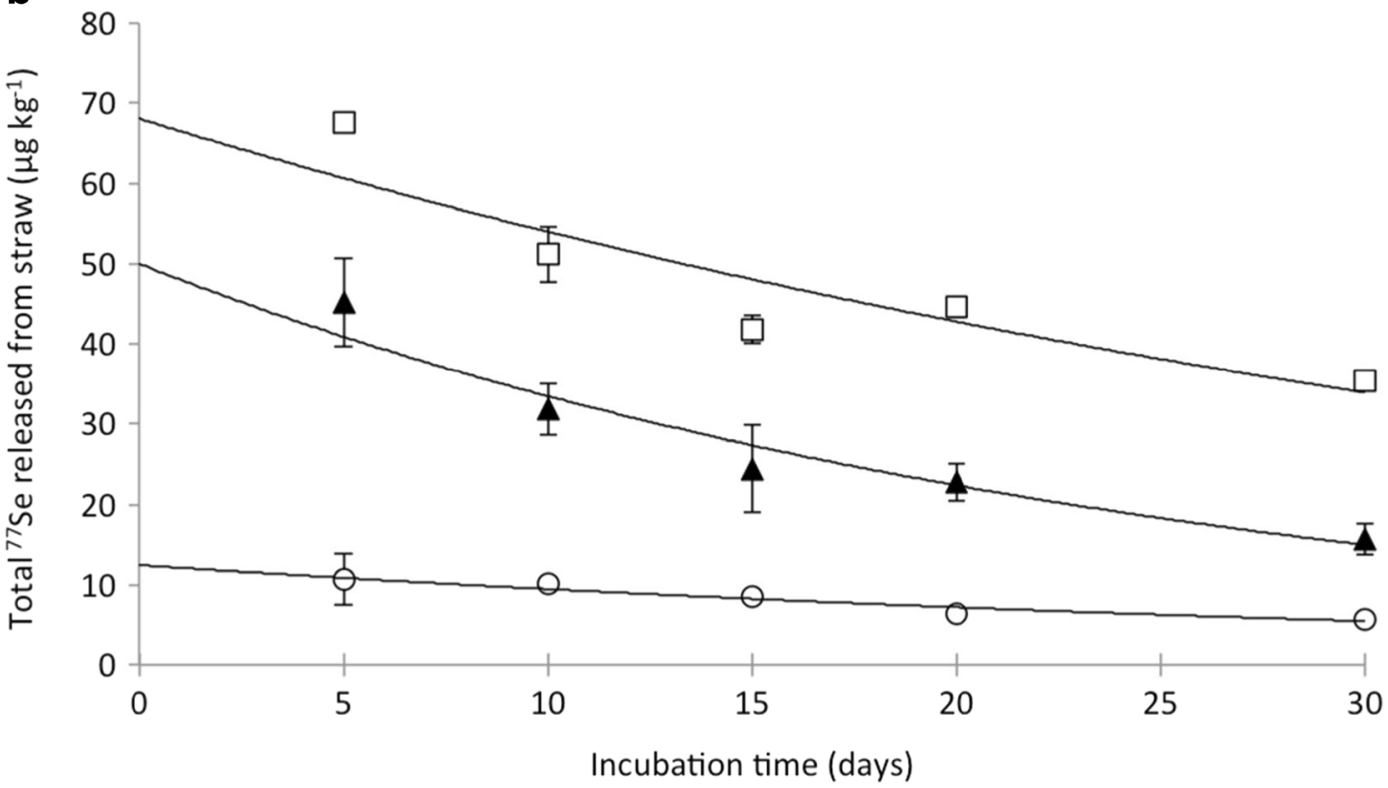

Fig. 4 Concentration of phosphate-extractable a) ${ }^{77} \mathrm{Se}^{\mathrm{VI}}$ fert and b) total ${ }^{77} \mathrm{Se}_{\text {fert }}$, released from ${ }^{77} \mathrm{Se}$-enriched wheat straw (from first harvest, $\mathrm{H} 1$, of the $\mathrm{DH}$ site) added at three application levels: $200 \mathrm{mg}(\circ), 500 \mathrm{mg}(\boldsymbol{\Delta})$ and $1000 \mathrm{mg}(\square)$ in $5 \mathrm{~g}$ moist soil, as a

distribution and transformation within the wheat plant was broadly the same for both soil- and fertilizerderived Se. This is despite differences in (i) the quantity of Se taken up by the crop from each source and (ii) relative availability during the growing season.

The relative bioavailability of ${ }^{77} \mathrm{Se}_{\text {fert }}$ and native soil $\mathrm{Se}\left(\mathrm{Se}_{\mathrm{N}}\right)$ to wheat grain at $\mathrm{H} 1$ was calculated on function of incubation time (30 days). The initial ${ }^{77} \mathrm{Se}_{\text {fert }}$ concentration in the straw was $219 \mu \mathrm{g} \mathrm{kg}^{-1}$. Solid lines represent the fit of an irreversible first order equation. Error bars show the standard error of three replicate analyses

a ratio basis $B_{R}$ from Eq. 10:

$B_{R}=\frac{{ }^{77} \mathrm{~S} e_{\text {fert }-G} \times S e_{N}}{{ }^{77} \mathrm{~S} e_{\text {fert }} \times S e_{N-G}}$

Where, $\mathrm{Se}_{\mathrm{N}}$ is the concentration of native soil derived Se present at each site, ${ }^{77} \mathrm{Se}_{\text {fert-G }}$ is the concentration of 
applied ${ }^{77} \mathrm{Se}$ recovered in wheat grain at $\mathrm{H} 1$ and $\mathrm{Se}_{\mathrm{N}-\mathrm{G}}$ is the concentration of native soil Se recovered in wheat grain at $\mathrm{H} 1$. All concentrations are expressed in $\mu \mathrm{g} \mathrm{kg}^{-1}$.

Bioavailability ratios of ${ }^{77} \mathrm{Se}_{\text {fert }}: \mathrm{Se}_{\mathrm{N}}$ in wheat grain $(\mathrm{DH}=338 ; \mathrm{NEW}=537$; WOR $=1221)$ confirmed that

${ }^{77} \mathrm{Se}_{\text {fert }}$ was $2-3$ orders of magnitude more bioavailable than $\mathrm{Se}_{\mathrm{N}}$ at all sites $(p<0.001)$. This was expected due to the highly soluble nature of newly added $\mathrm{Se}^{\mathrm{VI}}$ under neutral to alkaline soil pH conditions (Fordyce 2005) (Table 1). The bioavailability ratios of ${ }^{77} \mathrm{Se}_{\text {fert }}: \mathrm{Se}_{\mathrm{N}}$ at the DH and NEW sites are of the same order of magnitude to those calculated from other field-based cereal biofortification studies, (126-405, Stroud et al. 2010a; 51.7-324, Chilimba et al. 2012a; 125-208, Galinha et al. 2012). The bioavailability ratios of ${ }^{77} \mathrm{Se}_{\text {fert }}: \mathrm{Se}_{\mathrm{N}}$ were also significantly different between sites (T-test; $P<0.001)$, most likely due to differences in soil properties and weather conditions at the time of application, etc.

Release of selenium-77 $\left({ }^{77} \mathrm{Se}_{\text {fert }}\right)$ from straw decomposition and fixation in soil

The straw incubation data showed that ${ }^{77} \mathrm{Se}^{\mathrm{VI}}$ accounted for almost all inorganic ${ }^{77} \mathrm{Se}$ released from ${ }^{77} \mathrm{Se}-$ enriched straw incubated in moist soil - less than $4 \%$ was present as selenite. On average, $35.9 \%$ (S.E. = $5.4 \%$ ) of total ${ }^{77} \mathrm{Se}$ was released over 30 days incubation. The speciation of the remaining ${ }^{77}$ Se released from straw was not determined but is likely to exist as in organic forms (selenomethionine; selenocystine). Stadlober et al. (2001) conducted a pot trial, in which a range of crops (winter wheat, spring wheat, summer barley, summer rye and durum wheat) were fertilised with $\mathrm{Na}_{2} \mathrm{SeO}_{4}$ at a rate equivalent to $56.3 \mathrm{~g} \mathrm{ha}^{-1}$. Speciation analysis (by HPLC-ICP-MS) of the resulting wheat crop showed substantial conversion of applied $\mathrm{Se}^{\mathrm{VI}}$ to selenomethionine (69-86\%) and to a lesser degree selenocystine $(7-13 \%)$. The steady decrease in phosphate-extractable ${ }^{77} \mathrm{Se}^{\mathrm{VI}}$ (Fig. 4) suggests gradual incorporation of labile ${ }^{77} \mathrm{Se}^{\mathrm{IV}}$ into complexes with soil humus or reduction to other recalcitrant forms (e.g. $\mathrm{Se}^{0}$ ) which resist extraction by $\mathrm{KH}_{2} \mathrm{PO}_{4}$. Results from the soil incubation experiment showed no measurable selenate $\left({ }^{77} \mathrm{Se}^{\mathrm{VI}}\right)$ from spike addition in $\mathrm{KH}_{2} \mathrm{PO}_{4}$ extracts in the DH and NEW soils at any stage. In the context of this study, this suggests negligible adsorption of ${ }^{77} \mathrm{Se}^{\mathrm{VI}}$ by hydrous oxides and instead direct incorporation of labile ${ }^{77} \mathrm{Se}^{\mathrm{VI}}$ into organic complexes or reduction to recalcitrant forms. The majority (mean 69.9\%) of the decrease in total ${ }^{77} \mathrm{Se}_{\text {fert }}$ released from the straw through time (Fig. 4) can be ascribed to the observed decrease in ${ }^{77} \mathrm{Se}^{\mathrm{VI}}{ }_{\mathrm{P}}$. The apparent half-lives of fixation of ${ }^{77} \mathrm{Se}$ released by decomposition of the enriched straw, at each rate of straw addition were $25.7 \mathrm{~d}(200 \mathrm{mg}), 17.3 \mathrm{~d}$ $(500 \mathrm{mg})$ and $30.1 \mathrm{~d}(1000 \mathrm{mg})$, (average $=23.1 \mathrm{~d}$; S.D. $=0.0089$ d). However, under field conditions (compared to those in the laboratory), the greater particle size of incorporated straw (chopped rather than milled) and the lower average soil temperature for the UK $\left(10^{\circ} \mathrm{C}\right.$ rather than $21^{\circ} \mathrm{C}$ ) would likely result in a much slower rate of straw decomposition.

The potential increases in soil ${ }^{77} \mathrm{Se}$ from decomposition of ${ }^{77} \mathrm{Se}$-enriched straw at each site were 0.335 , 0.142 and $0.179 \mu \mathrm{g}{ }^{77} \mathrm{Se} \mathrm{kg} \mathrm{soil}{ }^{-1}$ year ${ }^{-1}$ at the $\mathrm{DH}$, NEW and WOR sites, respectively. Broadley et al. (2010) reported similar potential increases of soil Se from incorporation of Se-enriched winter wheat crop residues $\left(0.33-0.67 \mu \mathrm{g} \mathrm{Se} \mathrm{kg} \mathrm{soil}{ }^{-1}\right.$ year $\left.^{-1}\right)$, from initial application rates of 5-100 $\mathrm{g} \mathrm{Na}_{2} \mathrm{SeO}_{4} \mathrm{ha}^{-1}$. Dhillon et al. (2007) reported that Se-enriched crop residues containing $\leq 137 \mathrm{mg} \mathrm{Se} \mathrm{kg}^{-1}$ could be incorporated into nonseleniferous topsoils, without the risk of Se toxicity in subsequently grown cereal crops.

Retention of soil selenium- $77\left({ }^{77} \mathrm{Se}_{\text {fert }}\right)$ in topsoil

Monthly rainfall figures for the summer of 2012 in comparison to the long-term average are illustrated in Fig. 5. The summer of 2012 in the UK was the wettest for a century, which is apparent from the record rainfall figures recorded in June and July at Sutton Bonington (Fig. 5). Rainfall in the month of ${ }^{77} \mathrm{Se}$ application (May 2012) was below the long-term average (Fig. 5), this suggests rainfall was low within the first two to three weeks post application before it increased sharply in June. Results from the incubation experiment (Fig. 4), showed that between 10 and $20 \%$ of ${ }^{77} \mathrm{Se}^{\mathrm{VI}}$ from spike addition was likely to be fixed in the DH and NEW topsoils, within the first two to three weeks after spiking. As previously mentioned, the $\mathrm{KH}_{2} \mathrm{PO}_{4}$ extracts of the $\mathrm{DH}$ and NEW topsoils did not contain any ${ }^{77} \mathrm{Se}^{\mathrm{VI}}$ from the spike application at any point during the incubation, suggesting the vast majority ( $>80 \%$ ) of ${ }^{77} \mathrm{Se}^{\mathrm{VI}}$ from application was present in the soil solution in a labile state, two to three weeks after spiking. In the context of this study, the measureable retention of ${ }^{77} \mathrm{Se}_{\text {fert }}$ observed in topsoil at all sites at $\mathrm{H} 1$ (15-31\%, Fig. 2) was similar 
to that observed over the first two to three weeks in the parallel soil incubation experiment (Fig. 3), suggesting that fixation and crop uptake of ${ }^{77} \mathrm{Se}_{\text {fert }}$ occurred rapidly (within the first month after application) after which the sustained period of heavy rainfall is likely to have removed the remaining labile ${ }^{77} \mathrm{Se}^{\mathrm{VI}}$ from the soil system via leaching.

The apparent isotopic ratio $\left({ }^{77} \mathrm{Se} /{ }^{78} \mathrm{Se}\right)$ was slightly greater than the expected value (0.321) in TMAH extracts of the WOR control soil, producing an apparent fertilizer Se residue (Fig. 2). It was hypothesised that these differences were likely due to an interference at ${ }^{77}(\mathrm{~m} / \mathrm{z})$ during ICP-MS analysis, which artificially elevated the ${ }^{77}(\mathrm{~m} / \mathrm{z}):^{78}(\mathrm{~m} / \mathrm{z})$ ratio in all samples, including controls. The two most likely interferences at ${ }^{77}(\mathrm{~m} / \mathrm{z})$ are the polyatomic species ${ }^{60} \mathrm{NiOH}^{+}\left({ }^{60} \mathrm{Ni}, 26.1 \%\right.$ abundance) and the hydride ${ }^{76} \mathrm{GeH}$. The contribution of ${ }^{60} \mathrm{NiOH}^{+}$to the ${ }^{77} \mathrm{Se}$ signal was investigated by $\mathrm{Ni}$ standard addition to TMAH extracts of the soils. However the interference from soil-derived $\mathrm{Ni}$, estimated by extrapolation of the ${ }^{77}(\mathrm{~m} / \mathrm{z}):{ }^{78}(\mathrm{~m} / \mathrm{z})$ ratio against Ni concentration, was very small and would only marginally increase the natural ${ }^{77}(\mathrm{~m} / \mathrm{z}):^{78}(\mathrm{~m} / \mathrm{z}$ ) ratios (DH 0.3224; NEW 0.3229; WOR 0.3235). Therefore, formation of ${ }^{60} \mathrm{NiOH}^{+}$species did not account for the elevated ${ }^{77}(\mathrm{~m} / \mathrm{z}):{ }^{78}(\mathrm{~m} / \mathrm{z})$ ratios observed in the WOR soil. By contrast, analysis of the Ge/Se ratio in the TMAH extractions appeared to explain the elevated $\mathrm{m} / \mathrm{z}, 77$ signal in the WOR soil. The Ge/Se ratios (from ${ }^{72} \mathrm{Ge}$ and ${ }^{78} \mathrm{Se}$ measurements) in the NEW, DH and WOR TMAH extracts were $0.37,0.97$ and 1.8 respectively and extrapolation of this ratio to $\mathrm{Ge} / \mathrm{Se}=$ zero against the measured $\left.{ }^{77}(\mathrm{~m} / \mathrm{z})\right)^{78}(\mathrm{~m} / \mathrm{z})$ signals gave a ratio of 0.323 . This is close to the expected value of 0.321 for ${ }^{77} \mathrm{Se} /{ }^{78} \mathrm{Se}$ in the absence of interference and suggests that the hydride species ${ }^{76} \mathrm{GeH}$ was the cause of an apparently elevated ${ }^{77} \mathrm{Se}$ isotopic abundance in the WOR soil. It is therefore recommended that future investigations quantify the extent of ${ }^{76} \mathrm{Ge}$ hydride formation and implement a more direct correction on ${ }^{77} \mathrm{Se}$ rather than relying on subtraction of apparent Se fertilizer residues in control soils. The alternative approach is simply to subtract 'apparent' ${ }^{77} \mathrm{Se}$ residues measured in the control soils (as in Fig. 1a).

The concentration of ${ }^{77} \mathrm{Se}_{\text {fert }}$ in subsoils (at $\mathrm{H} 1$ and S2) was similar to those of control topsoils at all sites (Fig. 2), confirming minimal retention of ${ }^{77} \mathrm{Se}_{\text {fert }}$ in the subsoil. Statistical analysis by Duncan's multiple range test (DMRT), indicated that the concentrations of ${ }^{77} \mathrm{Se}_{\text {fert }}$ in subsoils at the $\mathrm{DH}$ and NEW sites were not significantly different from those of controls. The concentration of ${ }^{77} \mathrm{Se}_{\text {fert }}$ in subsoil sampled at $\mathrm{H} 1$ at the WOR site was significantly different $(p<0.05)$ from subsoil sampled at $\mathrm{S} 2$, which was also significantly different from the control. The concentration of ${ }^{77} \mathrm{Se}_{\text {fert }}$ in all topsoil sampled was significantly different $(p<0.05)$ from controls, confirming measureable retention of ${ }^{77} \mathrm{Se}_{\text {fert }}$, which was still present 15 months after application (H2). The difference in the concentration of ${ }^{77} \mathrm{Se}_{\text {fert }}$ in topsoil, between $\mathrm{H} 1$ and S2 was significant $(p<0.05)$ at the NEW and WOR sites. This decrease is likely to have occurred as a result of ploughing after H1, causing topsoil inversion. Fixation of ${ }^{77} \mathrm{Se}_{\text {fert }}$ is likely to have occurred primarily near the surface, producing a concentration gradient throughout the topsoil and into the subsoil. Ploughing would cause the most enriched layer (near the surface) to be buried at plough depth, which depending on plough depth and soil sampling depth may not be recovered, resulting in an incomplete audit of soil Se. Bhogal (1995) observed a similar effect with applied ${ }^{15} \mathrm{~N}$ at Ropsley. In the context of this study, it is worth noting that other losses of ${ }^{77} \mathrm{Se}_{\text {fert }}$ from topsoil may have occurred via leaching or reduction of ${ }^{77} \mathrm{Se}_{\text {fert }}$ to recalcitrant forms, which were not extracted with TMAH. The difference in concentration of ${ }^{77} \mathrm{Se}_{\text {fert }}$ in topsoil between $\mathrm{S} 2$ and $\mathrm{H} 2$ was significant $(p<0.05)$ at all sites (Fig. 2b). This increase cannot be ascribed to re-inversion of topsoil because sampling was undertaken prior to ploughing. However, decomposition of wheat straw residues from $\mathrm{H} 1$ enriched with ${ }^{77} \mathrm{Se}_{\text {fert }}$, due to increased soil temperatures during the spring and summer, may have contributed to the apparent increase in the concentration of ${ }^{77} \mathrm{Se}_{\text {fert }}$ in topsoil at H2. Smith and Douglas (1971) observed that the content of nitrogen $(\mathrm{N})$ in $\mathrm{N}$ enriched wheat straw remained stable in soils below $4{ }^{\circ} \mathrm{C}$ and decreased significantly with increasing soil temperature above $4{ }^{\circ} \mathrm{C}$ due to increased rates of straw decomposition.

The potential increase in soil ${ }^{77} \mathrm{Se}_{\text {fert }}$ at each site from incorporation of ${ }^{77} \mathrm{Se}$-enriched wheat straw (calculated using Equation 2) would account for 147, 38.5 and $55.1 \%$ of the observed increase in ${ }^{77} \mathrm{Se}_{\text {fert }}$ concentration at the DH, NEW and WOR sites respectively between $\mathrm{S} 2$ and H2. However, this calculation makes the 
Fig. 5 Rainfall data (mm) collected at Sutton Bonington weather station (grid ref.: $52^{\circ} 50^{\prime}$ $\left.11.34^{\prime \prime} \mathrm{N}-1^{\circ} 15^{\prime} 04.25^{\prime \prime} \mathrm{W}\right)$, for months April - August (inclusive) 2012, compared with the long term average (2002-2012). Error bars show the standard deviation of all monthly measurements from 2002 to 2012 (inclusive)

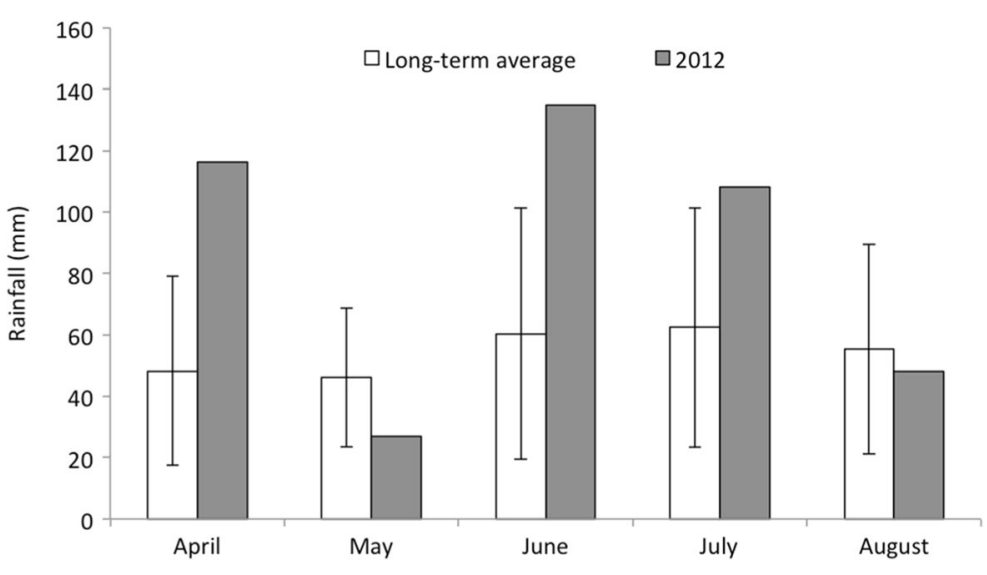

assumption that all ${ }^{77} \mathrm{Se}_{\text {fert }}$ present in crop residues is released by decomposition and subsequently retained by soil between $\mathrm{S} 2$ and $\mathrm{H} 2$, which may not be the case.

Residual crop selenium-77

Negligible residual ${ }^{77} \mathrm{Se}_{\text {fert }}$ was detected in crops harvested the following year after application, at all sites (Table 3). This confirmed that ${ }^{77} \mathrm{Se}_{\text {fert }}$ retained in topsoil from the initial application, and the minor incorporation of crop residue practiced on the experimental plots, was almost entirely present in a non-bioavailable form. Gupta et al. (1993) applied $\mathrm{Na}_{2} \mathrm{SeO}_{4}$ at three application rates $\left(10,20\right.$ and $\left.40 \mathrm{~g} \mathrm{ha}^{-1}\right)$ to barley in Canada and observed no evidence of residual Se in crops the year following application (regardless of application rate). Stroud et al. (2010a) observed no significant difference in grain $\mathrm{Se}$ concentrations in winter wheat, grown the year after application with 10 or $20 \mathrm{~g} \mathrm{ha}^{-1} \mathrm{Na}_{2} \mathrm{SeO}_{4}$, compared to controls. Chilimba et al. (2012b) observed very small recoveries $(2.0$ and $0.78 \%)$ of isotopically labelled Se (applied as aqueous $\mathrm{Na}_{2}{ }^{74} \mathrm{SeO}_{4}$ at a rate of $10 \mathrm{~g} \mathrm{ha}^{-1}$ ) in the grain of maize crops grown the year after application, across two field sites in Malawi. However, at higher application rates (up to $100 \mathrm{~g} \mathrm{ha}^{-1}$ ), the presence of applied Se in the grain of maize crops, grown the year after application, has been observed and also has a linear response to application rate (Chilimba et al. 2012b).

\section{Conclusions}

Application of $10 \mathrm{~g}^{77} \mathrm{Se}^{\mathrm{VI}} \mathrm{ha}^{-1}$ was sufficient to boost wheat grain concentrations by 4-13 times their control levels, equating to a recovery of $12-15 \%$ of the added fertilizer. Despite application during one of the wettest summers on record for the area, the timing of application was sufficiently far enough removed (2-3 weeks) from the period of intense rainfall for uptake by crops and fixation in soils to occur.

On average $22 \%$ (standard deviation $=8.07 \%$ ) of ${ }^{77} \mathrm{Se}_{\text {fert }}$ was retained in the topsoil. However, virtually all the ${ }^{77} \mathrm{Se}$ retained was non-bioavailable at the rate of application used in this study - there was no evidence of a significant residual effect on second crops. At the rate of residual Se accumulation observed it would take several centuries for soil Se concentration at the field trial sites to reach double the current level: $\mathrm{DH}=621 \mathrm{y}$; $\mathrm{NEW}=326 \mathrm{y} ; \mathrm{WOR}=456 \mathrm{y}$. Given such small annual additions to soil Se loading and the apparently rapid immobilization of selenate in the topsoil, it appears unlikely that long-term Se biofortification would present a significant toxic hazard to the soil environment. Perhaps the only remaining potential source of concern lies with the ${ }^{77} \mathrm{Se}$ losses observed at all three sites; on average this amounted to $40.1 \%$ (std dev: $3.05 \%$ ) of the original application. This was not recovered in the subsoil and so the suggestion is that it was lost from the soil through leaching

The negligible concentrations of ${ }^{77} \mathrm{Se}_{\text {fert }}$ detected in crops at second harvest (H2), suggests that biofortification of cereal crops in the UK with Se at a rate of $10 \mathrm{~g} \mathrm{Se}^{\mathrm{VI}} \mathrm{ha}^{-1}$, would have to be repeated annually to ensure effective grain enrichment. Although Se retention in soil does not provide a useful source for following crops, a possible source of residual Se may be the cereal straw, which on average absorbed $19.4 \%$ (std dev: $9.12 \%$ ) of the applied Se. The primary species of Se released during the decomposition of Se-enriched straw 
was identified as $\mathrm{Se}^{\mathrm{VI}}$, (selenate) which may provide a source of residual Se to subsequently grown crops. For this source of Se to provide an effective contribution to biofortification of a following crop the main issues to consider must be timing and extent of straw incorporation. The release rate will depend on the soil temperature and straw condition while uptake of released selenate will depend on the presence of a growing winter cereal crop, or possibly a catch crop to be ploughed in for a spring-sown cereal crop the following year. Stavridou et al. $(2011,2012)$ investigated several potential catch crops for Se and demonstrated both immobilization and mineralisation of Se following incorporation depending on the Se content of the catch crop. However, the usefulness of the catch crops in providing Se to springsown crops was generally limited by low Se uptake in Autumn. Further investigation should involve a fieldbased trial and should examine (i) the timing and extent of straw incorporation, (ii) alternative straw chopping and incorporation approaches, (iii) the alternative use of an Autumn-sown cereal or a fast growing catch crop for a subsequent Spring-sown cereal. Given the speciation of $\mathrm{Se}$ in straw $\left(\mathrm{Se}^{\mathrm{VI}}\right)$ and the proportion of Se originally applied (c. 20\%) it seems likely that some residual effect from Se release from straw should be possible and it would be important to quantify this in the event of biofortification strategies being widely adopted in the UK.

Acknowledgements This project was funded by the Lawes Agricultural Trust, Rothamsted Research (Charity number 208228) and the University of Nottingham, UK.

Open Access This article is distributed under the terms of the Creative Commons Attribution 4.0 International License (http:// creativecommons.org/licenses/by/4.0/), which permits unrestricted use, distribution, and reproduction in any medium, provided you give appropriate credit to the original author(s) and the source, provide a link to the Creative Commons license, and indicate if changes were made.

\section{References}

Alfthan, G., Aspila, P., Ekholm, P., Eurola, M., Hartikainen, H., Hero, H., Hietaniemi, V., Root, T., Salminen, P., Venäläinen, E.R., Aro, A. (2011) Nationwide supplementation of sodium selenate to commercial fertilizers: history and 25-year results from the Finnish selenium monitoring programme. Thompson B, Amoroso L (eds) Combating micronutrient deficiencies: Food-based approaches 312-337
Bhogal (1995) Ph. D. thesis (Effects of long-term nitrogen applications on nitrogen cycling under continuous wheat). The University of Nottingham, pp. 205-208

British Nutrition Foundation (2001) Briefing Paper: Selenium and Health. https://www.nutrition.org.uk/attachments/145 Selenium and health.pdf

Broadley MR, Alcock J, Alford J, Cartwright P, Foot I, Fairweather-Tait SJ, Hart DJ, Hurst R, Knott P, Mcgrath SP, Meacham MC, Norman K, Mowat H, Scott P, Stroud JL, Tovey M, Tucker M, White PJ, Young SD, Zhao F (2010) Selenium biofortification of high-yielding winter wheat (Triticum aestivum L.) by liquid or granular Se fertilisation. Plant Soil 332:5-18

Chen L, Yang F, Xu J, Hu Y, Hu Q, Zhang Y, Pan G (2002) Determination of selenium concentration of rice in China and effect of fertilization of selenite and selenate on selenium content of rice. J Agric Food Chem 50:5128-5130

Chilimba ADC, Young SD, Black CR, Meacham MC, Lammel J, Broadley MR (2012a) Agronomic biofortification of maize with selenium (Se) in Malawi. Field Crop Res 125:118-128

Chilimba ADC, Young SD, Black CR, Meacham MC, Lammel J, Broadley MR (2012b) Assessing residual availability of selenium applied to maize crops in Malawi. Field Crop Res 134:11-18

Collins RN, Tran ND, Bakkaus E, Avoscan L, Gouget B (2006) Assessment of Isotope Exchange Methodology to Determine the Sorption Coefficient and Isotopically Exchangeable Concentration of Selenium in Soils and Sediments. Environ Sci Technol 40:7778-7783

Curtin D, Hanson R, Van der Weerden TJ (2008) Effect of selenium fertiliser formulation and rate of application on selenium concentrations in irrigated and dryland wheat (Triticum aestivum). N Z J Crop Hortic Sci 36:1-7

Dhillon SK, Hundal BK, Dhillon KS (2007) Bioavailability of selenium to forage crops in a sandy loam soil amended with Se-rich plant materials. Chemosphere 66:1734-1743

Di Tullo P, Pannier F, Thiry Y, Le Hécho I, Bueno M (2016) Field study of time-dependent selenium partitioning in soils using isotopically enriched stable selenium tracer. Sci Total Environ 562:280-288

Ducsay L, Ložek O (2006) Effect of selenium foliar application on its content in winter wheat grain. Plant Soil Environ 52:7882

Eurola, M.H. (2005) Twenty years of selenium fertilization. MMT agrifoods research reports 69, Jokioinen, Finland

Fleming GA (1980) Essential Micronutrients 11: Iodine and Selenium. In: Davis BE (ed) Applied Soil Trace Elements. Wiley, New York, pp 199-234

Fordyce F (2005) Selenium deficiency and toxicity in the environment. In: Selninus O, Alloway B, Centeno J, Kinkelman R, Fuge R, Lindh U, Smedley P (eds) Essentials of Medical Geology. Elsevier, London, pp 373-415

Galinha G, Freitas MC, Pacheco AMG, Coutinho J, Maçãs B, Almeida AS (2012) Determination of selenium in breadwheat samples grown under a Se-supplementation regime in actual field conditions. Radioanal Nuclear Chem 291: 231-235

Gissel-Nielsen G (1998) Effects of selenium supplementation of field crops. In: Frankenberger WT, Engberg RA (eds) Environmental Chemistry of Selenium. Marcel-Dekker, New York, pp 99-112 
Gupta UC, Winter KA, Sanderson JB (1993) Selenium content of barley as influenced by selenite-enriched and selenateenriched fertilizers. Commun Soil Sci Plant Anal 24:11651170

Gupta UC, Gupta SC (2002) Quality of animal and human life as affected by selenium management of soils and crops. Commun Soil Sci Plant Anal 33:2537-2555

Jacobs, L.W., 1989. Selenium in Agriculture and the Environment [Soil Science Society of America Special Publication no. 23]. Madison: American Society of Agronomy and Soil Science Society of America

Keskinen R, Räty M, Yli-Halla M (2011) Selenium fractions in selenate-fertilized field soils of Finland. Nutr Cycl Agroecosyst 91:17-29

Konert M, Vandenberghe J (1997) Comparison of laser grain size analysis with pipette and sieve analysis: a solution for the underestimation of the clay fraction. Sedimentology 44:523535

Lane PW, Mcgrath SP (1994) Modelling the effect of cultivation on the dispersion of pollutants in soil. Statistician 4:537-549

Large EC (1954) Growth in cereals - illustration of the Feekes scale. Plant Pathol 3:128-129

Li H, Mcgrath SP, Zhao F (2008) Selenium uptake, translocation, and speciation in wheat supplied with selenate or selenite. New Phytol 178:92-102

Lyons GH, Lewis J, Lorimer MF, Holloway RE, Brace DM, Stangoulis JCR, Graham RD (2004) High-selenium wheat: Agronomic biofortification studies to improve human nutrition. Food Agric Environ 2:171-178

Martens DA, Suarez DL (1997) Selenium speciation of soil/ sediment determined with sequential extractions and hydride generation atomic absorption spectrophotometry. Environ Sci Technol 31:133-139

Neal RH (1995) Selenium. In: Alloway BJ (ed) Heavy Metals in Soils. Blackie Academic \& Professional, London, pp 260283

Public Health England and The Food Standards Agency (2014). National diet and nutrition survey. Results from years 1-4 (combined) of the rolling programme (2008/2009 and 2011/12) revised February 2017. Available at: https://www. gov.uk/government/uploads/system/uploads/attachment data/file/594361/ndns_y1_to_4_uk_report_full_text_ revised_february_2017.pdf

Rawlins, B.G., Mcgrath, S.P., Scheib, A.J., Breward, N., Cave, M., Lister, T.R., Ingham, M., Gowing, C., Carter, S., 2012. The advanced soil geochemical atlas of England and Wales. British Geological Survey, Keyworth, available from: www. bgs.ac.uk/gbase/advsoilatlasEW.html

Rimmer DL, Shiel RS, Syers JK (1990) Effects of soil application of selenium on pasture composition. J Sci Food Agric 51: 407-410

Ros GH, Van Rotterdam AMD, Bussink DW, Bindraban PS (2016) Selenium fertilization strategies for bio-fortification of food: an agro-ecosystem approach. Plant Soil 404:99-112

Shand C, Coutts G, Duff E, Atkinson D (1992) Soil selenium treatments to ameliorate selenium deficiency in herbage. Sci Food Agric 59:27-35
Smith JH, Douglas CL (1971) Wheat straw decomposition in the field. Soil Soc Am Proc 35:269-272

Stadlober M, Sager M, Irgolic KJ (2001) Effects of selenate supplemented fertilisation on the selenium level of cereals identification and quantification of selenium compounds by HPLC-ICP-MS. Food Chem 73:357-366

Stavridou E, Thorup-Kristensen K, Young SD (2011) Assessment of selenium mineralization and availability from catch crops. Soil Use Manag 27:305-311

Stavridou E, Young SD, Thorup-Kristensen K (2012) The effect of catch crop species on selenium availability for succeeding crops. Plant Soil 351:149-160

Stephen RC, Saville DJ, Watkinson JH (1989) The effects of sodium selenate applications on growth and selenium concentrations in wheat. N Z J Crop Hortic Sci 17:229-237

Stroud JL, Li HF, Lopez-Bellido FJ, Broadley MR, Foot I, Fairweather-Tait SJ, Hart DJ, Hurst R, Knott P, Mowat H, Norman K, Scott P, Tucker M, White PJ, Mcgrath SP, Zhao FJ (2010b) Impact of sulphur fertilisation on crop response to selenium fertilisation. Plant Soil 332:31-40

Stroud JL, Broadley MR, Foot I, Fairweather-Tait SJ, Hart DJ, Hurst R, Knott P, Mowat H, Norman K, Scott P, Tucker M, White PJ, Mcgrath SP, Zhao FJ (2010a) Soil factors affecting selenium concentration in wheat grain and the fate and speciation of Se fertilisers applied to soil. Plant Soil 332:19-30

Valle G, Mcdowell L, Prichard D, Chenoweth P, Wright D, Martin D, Kunkle B, Wilkinson N (2002) Selenium concentration of fescue and bahiagrasses after applying a selenium fertilizer. Commun Soil Sci Plant Anal 33:1461-1472

Wang JW, Wang ZH, Mao H, Zhao HB, Huang DL (2013) Increasing Se concentration in maize grain with soil- or foliar-applied selenite on the Loess Plateau in China. Field Crop Res 150:83-90

Watts MJ, Mitchell CJ (2009) A pilot study on iodine in soils of Greater Kabul and Nangarhar provinces of Afghanistan. Environ Geochem Health 31:502-509

Whelan BR (1989) Uptake of selenite fertiliser by subterranean clover pasture in Western Australia. Aust J Exp Agric 29: 517-522

World Health Organisation., 2011. Selenium in drinking water. Background document for development of WHO Guidelines for Drinking-water Quality

Ylaranta T (1983) Sorption of selenite and selenate in the soil. Annales Agriculturae Fenniae 22:29-39

Zadoks JC, Chang TT, Konzak CF (1974) Decimal code for growth stages of cereals. Weed Res 14:415-421

Zając T, Oleksy A, Stokłosa A, Klimek-Kopyra A, Macuda J (2013) Vertical distribution of dry mass in cereals straw and its loss during harvesting. Int Agrophys 27:89-95

Zayed A, Lytle CM, Terry N (1998) Accumulation and volatilization of different chemical species of selenium by plants. Planta 206:284-292

Zhao CY, Ren JG, Xue CZ, Lin ED (2005) Study on the relationship between soil selenium and plant selenium uptake. Plant Soil 277:197-206

Zhao FJ, Mcgrath SP (1994) Extractable sulfate and organic sulfur in soils and their availability to plants. Plant Soil 164:243250 